\title{
$\therefore \operatorname{alccon}$ \\ cooperazione | non profit
}

\section{Working}

Papers

153

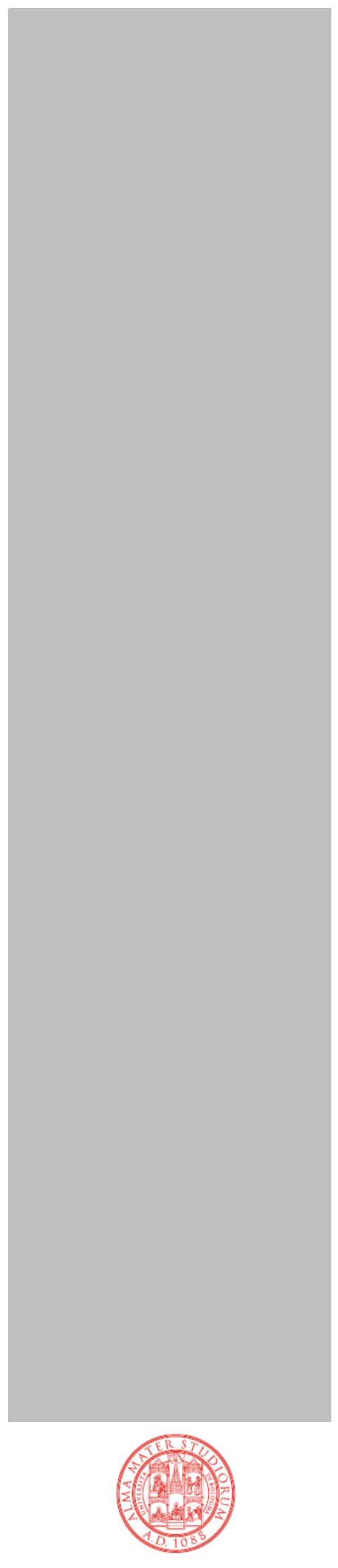




\title{
Gamblers, scratchers and their financial education
}

\author{
Leonardo Becchetti, University of Rome Tor Vergata \\ Davide Bellucci, University of Rome Tor Vergata \\ Fiammetta Rossetti, European Commission, JRC Institute for Prospective Technological Studies
}

\begin{abstract}
We develop an online survey to investigate the characteristics of slot/videopoker players and scratchers (individuals buying tickets of scratch-off lotteries). We find evidence of a negative relationship between gambling and financial literacy. More specifically, after controlling for gender, education, income, employment status and area of residence: i) slot and/or videopoker players have a 8 percent lower probability of answering correctly to all the three standard financial education questions; ii) scratch-off players have a 10 percent lower probability of answering correctly to the (third) mutual fund risk diversification question. Scratch-off players are as well more impatient and more likely to sacrifice expected value for positive skewness and they overestimate the probability of winning at least the price of the ticket. Our findings suggest that scratchers and slot/videopoker players may be unable to evaluate the overall consequences of gambling on their economic wellbeing due to their lower financial education.
\end{abstract}

Keyword: gambling, scratch-off lotteries, financial education.

JEL numbers: G02 (Behavioral Finance: Underlying Principles) G11 (Portfolio Choice, Investment Decisions) A20 (Economics education and teaching of economics); D14 (Household Saving, Personal Finance)

\section{Introduction}

Why individuals should buy an asset with negative expected returns as they do when acquiring scratchoff lottery tickets and/or playing with slot machines? Does it happen because they suffer from a cognitive bias on asset characteristics or because they have preferences for some specific features of that asset (such as the positive skewness determined by the possibility of large but unlikely wins)? Are as well buyers of these particular assets enough financially educated to evaluate the consequences of their choices on their economic conditions? This paper tries to provide answers to these questions with an empirical 
analysis on biases, preferences and financial education of selected different groups of "gamblers" such as buyers of scratch-off tickets and slot/videopoker players. ${ }^{1}$

The reasons why people play lotteries, and allow games of chance to take so much out of their wallets and lives despite low payout rates and remote odds of winning inspired many contributions in the literature. According to Friedman and Savage (1948) risk-averse people enter unfair gambles with the hope of significantly improving their living standards. Kahneman and Tversky (1979) argue that lottery players actually over-weight the low chances associated to colossal jackpots and that the popularity of lotteries (and of slot machine games) is in fact due to their low cost chance of winning huge amounts of money. Alternative explanations suggest that when smaller prizes are offered in addition to the jackpot then playing the lottery is a utility maximizing behaviour consistent with players' preferences (Quiggin, 1991). Garrett and Sobel (1999) use data about on-line lotteries in United States and find that gamblers, even if risk-averse, love the positive skewness of returns. The skewness of prize distributions thrills players more than high risk prevents them from betting. Other authors document that effective advertisement is crucial in providing state lotteries with public credibility (Griffiths and Wood, 2001) ${ }^{2}$.

Stewart (1996) argues that bettors on their side have often scarce knowledge of the probability theory and may remain entrapped by the sunk costs that drive them to play repeatedly the same number until it comes to win (Walker, 1992). A number of additional individual biases contribute to distort the imaginary of lotteries and other games of chances such as those provided by slot machines. Because of the illusion

\footnotetext{
${ }^{1}$ We put together in our research generic slot machine and videopoker play since the latter, in spite of the name, is just a variant of the typical slot machine play and quite dissimilar from a poker game with human players. In the videopoker game players receive randomly drawn cards and can change them once. They then receive a money prize in proportion to the points obtained with the combination of cards. Traditional slot machines and videopoker are therefore quite similar with changes in the symbols used (cards for videopoker play and objects for traditional slot machine play).

${ }^{2}$ The location and the number of gambling outlets in a specified area and the use of advertising to push people to gamble (Cornish 1978) have a role in the first decision to gamble, and may attract particular socioeconomic classes towards specific kinds of gambling. The working class watches more television (Walker, 1992), therefore the marketing of lotteries, slot machines and videopoker on television may have a higher impact on this group. This explains why the working class is over represented while the middle class is underrepresented among players of these games (Clotfelter and Cook, 1991). In addition to it, draws broadcasted on TV highlight the simplicity of winning while hiding the huge number of losers (Walker 1992), and slogans are designed to make people think they have good chances (rather than the actual odds) to win (Stearns and Borna, 1995).
} 
of control (Langer, 1975) gamblers may grow into the impression of building new skills about the gamble they usually play, while as a result of flexible attributions bettors start considering their losses either as close-to-wins or outcomes they had somehow predicted (Gilovich, 1983). Moreover, representativeness bias (Kahneman and Tversky, 1971; Guryan and Kearne, 2008) and availability bias (Tversky and Kahneman, 1973) let individuals believe that outcomes randomly drawn from the population are representative of the population itself, and judge the likelihood of outcomes by the relative ease with which these cases cross their mind. Aggressive advertisement, for example, meet the latter cognitive bias since strongly advertised positive but unrealistic gains come to appear much more possible (therefore "available") than what they actually are. Eventually online gambling offered with slot machines and videopoker play as the new frontier of state lotteries display new peculiarities with respect to other more traditional gambling ways (Philander and MacKay, 2014). Additional concerns rise when the game - with its gains and losses - becomes less related to face-to-face human interactions with the risk of reinforcing cognitive biases of the gamblers.

Recently, the demographics of gamblers attracted the interest of both economists and phycologists in order to gain ground on the understanding of particular gamblers' traits, especially about individuals who are at risk of dependence. Studies about Scandinavian countries (Nordmyr et al., 2014; Volberg et al., 2001) revealed that males have a much higher propensity toward the risk of gambling. Still being younger than 25 , foreigner, single, living in a big city, and receiving social welfare payments are additional features of individuals who may end up with gambling addiction (Nordmyr et al., 2014). Gambling addiction raises even more concerns when vulnerable and underage individuals are considered. Many studies address the issue of gambling of adolescents in association with other "problematic behaviour" as to alcohol (French et al., 2008) or food (Fischer and Smith, 2008) in order to clarify when and how the pathological conduct (i.e. gambling addiction, problem drinking, binge eating) starts. Novel researches try to assess how problematic behaviours (e.g., gambling addiction) are characterised under the psychiatric perspective (Wood and Griffiths, 2004). This literature shows that losing control after a certain activity may result into higher frequencies of an activity (Barnes et al., 1999), but still having additional causes lying in 
individuals' characters (Parker et al., 2008; Fischer and Smith, 2008). Fang and Mowen (2009) examined motivations of slot players. By comparing four gambling activities - slot machines, skilled card games, sports betting, and promotional games - they found that, compared with other gamblers, slot machine gamblers were motivated by excitement, escape, and low self-esteem, whereas other gamblers tended to be motivated primarily by money. In the same research perspective Clarke (2005) investigated motivational differences between slot machine and lottery players. Compared with lottery players, slot machine gamblers scored higher on motivation for stimulation, tension release, and feelings of importance, while revealing almost equal high motivation explained by rewards.

In recent times the problem of gambling raised as well the interest and concerns of institutions. The European Commission (EC) started evaluating some types of games (i.e. online betting) in order to gain knowledge about key drivers of problem gambling the threatens European citizens from beyond the borders of their countries. The Directorate-General for Internal Market, Industry, Entrepreneurship and SMEs of the EC is responsible - among other tasks - for "completing the Internal Market for goods and services", and lists gambling among the sectors where this task must be monitored and achieved across Europe. According to the EC "the EU gambling market is estimated at around EUR 84.9 billion and grows at a yearly rate of around 3\%", and the 2011 report by the European State Lotteries and Toto Association (2011) ranked Italy as "the largest instant market" of EU Member States, "with $€ 3.1$ bn in gross gambling revenue". In 2011 the EC started a public consultation to reflect on "the existence and extent of societal and public order risks" that associate to online lotteries to develop policy measures protecting "consumers, minors and vulnerable groups" against the risks of "illicit and unauthorised online gambling” (Green Paper, 2011). Unfair communication and gambling addiction are delicate aspects in all raffles, whether offline or online. Accordingly, in the Green Paper on online gambling the EC attentively considers the issues of misleading advertisement of lotteries - especially towards vulnerable groups, and acknowledges the existing national research endeavours about problem gambling.

The economic dimension of state licensed lotteries and their impact within society motivate the endeavours feeding into the present research work. We draw attention on a particular slice of state 
licensed lotteries, namely the market of scratch-off tickets together with two of the most important forms of online gambling represented by slot machines and videopoker. The activities have qualifying differences but also share important similarities such as those related to the distribution of payoffs for scratch-off tickets and slot machines. On the former (scratch-off lotteries) we gather the publicly available information about all the tickets that are currently being sold in Italy in order to have an overview of both jackpots and odds probabilities associated to them. We compare them with the very similar structure of the most recent vintage of slot machine play represented by videolottery machines (ie. vlt). This helps setting the scene for the second exercise we perform on survey data gathered by means of a questionnaire that we designed purposely to learn about individuals' socio-demographics, and their risk-preferences when it comes to betting on scratch-off tickets or playing slot/videopoker.

Our paper adds to the literature with two key contributions. First, we test whether gamblers suffer from cognitive bias, or whether they are rational and their gambling choices are consistent with their preferences. Second, we appraise the financial literacy of vlt and scratch-off players to check whether they significantly differ from the rest of the sample. To the best of our knowledge the latter point of our work has never been tested or discussed so far in the financial education literature and therefore represent an original contribution linking the two fields of gambling and financial education studies.

The paper is divided into six sections. In the second section we resume the specific characteristics of the games at stake. In the third section we illustrate the survey and the features of both scratch-off lotteries and slot/videopoker games with a special focus on Italy which is where we administered our survey. In the fourth section we present descriptive findings on characteristics, preferences and biases of players vs non players. In the fifth section we detail the econometric findings. The sixth section concludes.

\section{The peculiarities of scratch cards and slot machines}

State lotteries encompass different types of gambling of which the most renowned are lotto, instant lottery games, and video lottery terminals. In general, lotteries are now established and on average 
positively perceived because of their link with good causes (Griffiths and Wood, 2001). As gambling laws become more relaxed and gambling is just another product advertised by mass media, the risk of a higher gambling involvement gleams (Griffiths, 1997). Scratch tickets are claimed to have the potential of engendering repetitive habits in some consumers because they allow the psychological attitude of seeing losses as near-to-win experiences, offer rapid event frequency with short payout intervals, require no skill, and are highly accessible, "deceptively inexpensive and available in respectable outlets" (Griffiths, 2002; Jensen et al. 2013). Delfabbro and Winefield (2000) also observed irrational thinking characterising slot players about the possibility to predict or control gambling outcomes. Cote et al. (2003) found that losses perceived as near wins encourage continued gambling, with high similarities with scratch-off ticket and instant lotteries players. On the same strand Dixon et al. (2015) studied the effect of losses disguised as wins (LDWs), finding actually that, the more players were exposed to LDWs, the higher their win estimates, and conclude than that LDWs could increase the reinforcement rate of these games, despite not increasing payouts to gamblers.

Griffiths and Wood (2001) deepen the case for the UK arguing that scratch-off tickets should be considered "hard gambling", and ought not to be related to lotto that has precise gambling schedules. Instant lotteries tickets are an independent type of gambling giving a continuous opportunity to gamble in order to chase for large prizes. Evidence emerges from some European countries (Hendriks et al., 1997; Wood and Griffiths, 2004) that instant lotteries do constitute a problem to some people who either asked for help to clinics in their country, or have rung a national gambling helpline (Griffiths et al., 1999; Griffiths, 2000).

Special consideration must be dedicated to players who gamble to take risk and differ from individuals who just use scratch cards for recreational purposes. Disadvantaged individuals in terms of socioeconomics background may experience more harshly the consequences of lighter regulations about scratch-off tickets (Hendriks et al., 1997). Evidence witnesses an exacerbation of problem gambling within poorer and more vulnerable individuals after the launch of the National Lottery and Scratch Cards 
in UK (Shepherd et al, 1998). We test whether this is the case also in our sample by comparing sociodemographic characteristics of gamblers vis-à-vis the rest of respondents.

\section{The survey and the Italian market of scratch-off tickets}

In order to test biases, preferences and financial education of gamblers we structure an online survey divided into four sections. In the first section we ask respondents about habits and frequency of different types of gambling with special focus on scratch-off lotteries and two forms of online gambling (slot machines and videopoker games). The three types of games considered in our empirical analysis represent a growing and booming market in Italy. Italy is one of the countries with the highest per capita gambling expenditure in the world reaching 88 billion euros in 2015 (and yielding 8.7 billion tax income). This aggregate consumption volume corresponds to 10 percent of total consumption and 4 percent of GDP. The highest share of aggregate gambling expenditure comes from slot machines (55.8 percent) followed by online games whose income has grown three times in the last years. The third share is that of scratchoff lotteries. ${ }^{3}$ In the first section of the survey we account as well for standard socio-demographic factors (gender, age, education and works status) of the respondents and their parents plus some (smoking, and drinking) habits.

In the second section of the survey we measure biases and preferences and, more specifically, risk aversion, intertemporal preferences, taste for positive skewness and biased estimates of the probability to win with scratch-off lotteries. The survey is addressed to Italian respondents and refers to the whole range $(1,2,3,5,10$ and 20 euros) of tickets available in the country at the moment. In Table A1 and Figure A1 in Appendix we describe characteristics of Italian scratch-off tickets based on the distribution of winning probabilities publicly available on the website of Lottomatica S.p.A. which is the official dealer of Italian state owned lotteries. ${ }^{4}$ Prices and total revenues from different scratch-cards are reported in

\footnotetext{
${ }^{3}$ Italian Treasury data provided to the Parliament, 18 May 2016.

${ }^{4}$ http://www.lottomaticaitalia.it/grattaevinci/classico/probabilita-di-vincita.html
} 
columns 1 and 2. Expected gains from the jackpot in absolute term and as percentage of the ticket price are in columns 3 and 4 . Column 5 reports the total expected gain for each ticket. Columns 6 and 7 show the net loss in absolute value and as percentage of the ticket price. Kurtosis and skewness of the gambling odds for each ticket are listed in column 8 and 9. The last two columns (10 and 11) instead indicate kurtosis and skewness of prizes. Table A1 shows that the expected value of the jackpot is extremely low and buying a ticket implies on average an expected loss for any of the available tickets. The table also shows that scratch-off tickets are assets featured by leptokurtic distributions with high positive skewness. To make an example, by buying one of the 1 euro tickets the expected maximum jackpot gain is 12 cents while the net expected value (considering also non jackpot wins) ranges between -34 and -46 percent. The highest price (20 euro) ticket has as well an expected maximum jackpot gain of 4 euros (20 percent the price of the ticket) and a net expected loss ranging between - 15 and -21 percent. More generally, the table shows that the negative net expected gain falls as far as the price of the ticket grows. For each scratch-off ticket Figure A1 in the Appendix reports the expected gains with the matching gambling odds. The spark-lines offer the insightful visualisation of coupling expected gains and odds of gaining, and display the psychological role that huge jackpots may have in inflating the impression of possible gains in terms of both probability and amount.

If we compare these instant lottery characteristics with those of slot machine lotteries we find that the latter are somewhat converging to those of the former in terms of positive skewness and high value of the jackpot. Revenues of the Italian slot machine market are mainly produced by newslot (25,96 bln) and vlt machines (22,198 bln in 2015). The old vintage machines (newslot) have a lower payout (70 percent, hence a net expected gain of -30 percent for players), the maximum play is 1 euro coin currency and the maximum win 100 euros coin currency. The new vintage machines (vlt) have a higher payout (85 percent, hence a net expected gain of -15 percent for players), the maximum play is up to 10 euros in banknotes up to 500 euros and the maximum win 5000 euros, after three progressive jackpots arrives to a maximum of 500,000 euros. In the third section of the questionnaire 
we present the standard well known three financial education questions concerning respectively compounded interest, real return and mutual fund/risk diversification.

We conclude in the fourth section with questions on subjective wellbeing.

The questionnaire was online between March and June 2016.

A final draw for a voucher of $50 €$ to spend on products of a dedicated circuit was reserved only to those who completed the entire questionnaire in order to provide an incentive to its full compilation. Usual web controls were employed to avoid that respondents filled more than one questionnaire.

\section{Descriptive findings}

In Table 1 we present comparative summary descriptive statistics about the two groups of gamblers we focus on (i.e. slot/videopoker players, and scratch-off players), and about the respondents who do not play any of the two games (i.e. "non players"). We add a fourth group of respondents who declare not to buy scratch-off lotteries because they believe instant games not economically convenient. We think that this group proxies more closely the group of individuals who reject scratch-off lotteries thanks to the awareness of their economic drawbacks (such as their negative expected values described in the previous section and in Table A1 in the Appendix).

The group of those not playing any of the two games accounts for 45 percent of the sample, while 16.4 percent of the sample plays both games (46.9 percent play scratch-off lotteries while 24.5 percent play slot/videopoker).

Descriptive statistics commented below confirm that male gender, lower income and education, unemployment and retirement are all factors positively correlated with the probability of being player.

The gender difference matters only for slot/videopoker where 66 percent of players are males against 47 percent of scratch-off players and 45.5 percent among those not playing at both games. 
Scratch-off and slot/videopoker players have lower education than the non players' group. Almost one fourth of those playing slot/videopoker have no more than a middle school degree (22.34 percent) against only 5.43 percent of those not playing neither slot/videopoker nor scratch-off. Around 12 percent of slot/videopoker players have a graduate course degree against 16 percent of scratch-off players and around 27 percent of non players to both games. Parental education reflects similar characteristics. Scratch-off and slot/videopoker players have mothers whose education is not above elementary/middle school (41.9 and 57.14 percent respectively) against 30.65 of those not playing at both games. Similar patterns are found for father education with values that are respectively 37.96 and 52.29 percent for players of the two games against 32.44 percent of those not playing at both games. Only 23 percent of respondents whose mother has a graduate degree play scratch-off lotteries against 47 percent of the rest of the sample.

Scratch-off lotteries confirm to be regressive forms of taxation. Among respondents below the 55,000 euro yearly income threshold 48 percent "pay the scratch-off tax", while 32 percent pay it above the same income threshold. Looking at the income distribution of scratch-off players, around 75 percent are below the 25000 euro yearly income threshold, against 75.5 percent of slot/videopoker players and 69 percent of those playing to neither of the two games.

In terms of working status 60 percent of the unemployed play scratch-off lotteries against 45 percent of those not being unemployed. Unemployed are around 10.9 percent of our sample respondents but are 16 percent among those playing slot/videopoker and 7.5 percent among those not playing neither scratch-off lotteries nor slot/videopoker. Retired are 2.66 percent of the sample but 8 percent among those playing slot/videopoker and none among those saying that scratch-off is not economically convenient.

There are no big differences in habits between players and non players with the exception of smoking frequency especially for scratch-off players (53 percent) and relatively less for slot/videopoker payers (35.05 percent) with respect to those not playing both games (23.94 percent) (Table 2). 


\subsection{Financial preferences and biases}

In Table 3 we compare gamblers and non gamblers in terms of characteristics associated to financial preferences and biases.

There is no significant difference between scratchers and non scratchers in understanding the probability of winning the jackpot, except for the 1 euro ticket where scratchers are more likely to formulate the correct guess (11.8 against 5.26 percent). Always on the 1 euro ticket scratchers are slightly less likely to overestimate the probability of win (28.9 against 32 percent). They however overestimate more on the 2 euro ticket (36 percent against 29 percent). For all the remaining tickets $(3,5,10$ and 20 euros) we do not find clear cut patterns with a leading group in terms of over/underestimation of the probability of winning the jackpot. Overall, we cannot say that scratchers have a worse understanding than non scratchers of the winning probabilities. Our findings therefore reject the Kahneman-Tversky (1976) hypothesis that gamblers over-weight the low chances associated to colossal jackpots (Table 3, panel A). However for what regards the answers on how many tickets are needed on average to win at least the ticket price, we find that scratchers tend to underestimate systematically that number for tickets from 2 to 10 euros (Table 3, panel B). We may loosely relate this bias to the losses-disguised-as-wins (LDWs) problem. If scratchers believe that only few more bets are needed to recover the ticket price they are more likely to interpret a small gain as a win since they believe that, if below the ticket price, it is nonetheless bringing them closer to that amount of money. Our findings therefore do not reject the hypothesis of gambler bias on this specific point.

If biases partially discriminate between players and non players (at least the biases we measure here) preferences definitely do it.

Scratchers have a higher taste for asymmetry than non scratchers (Table 3, panel C). We measure this variable by proposing three different bets in increasing order in terms of asymmetry and decreasing order in terms of expected value (i.e. the first bet has the highest expected value and the lowest asymmetry, the 
last has the lowest expected value and the highest asymmetry). Among non scratchers 71.11 percent prefer the first bet against 59.9 percent among scratchers. The third bet (highest asymmetry, lowest expected value) is preferred by 23.83 percent of scratchers against 14.36 percent of non players of all considered games (scratch-off lotteries and slot/videopoker) (Pearson $\chi^{2}(2) \quad 6.29$, p-value 0.043).

Another characteristics that makes scratchers different is impatience (Table 3, panel D). We use a standard question measuring intertemporal preferences along 5 different choices with a trade-off between cashing 100 euros immediately versus a progressively higher sum to be cashed at a progressively higher time lag. We find that 88 percent of scratchers against 75 percent of non players of all considered games (scratch-off lotteries and slot/videopoker) are willing to forgo a 1 percent monthly interest or more to cash 100 euro immediately. The two distributions are significantly different (Pearson $\chi^{2}$ (4) 12.27, pvalue 0.015$)$.

These two characteristics (higher impatience and willingness to pay for asymmetry in terms of expected value) are consistent with scratchers' choice of buying financial assets (scratch-off tickets) with negative expected returns but high asymmetry and assets that can give cash soon even though their expected return is negative.

\subsection{Financial education of slot/videopoker and scratch-off players}

In this section we present findings of our test on financial literacy of slot/videopoker and scratch-off players vis-à-vis the rest of the sample.

In our questionnaire we propose the three standard questions of financial education reported below:

1. If you had $\$ 100$ in a saving account and the interest rate was $2 \%$ per year. After five years, how much do you think you would have in the account if you left the $\$ 100$ on the account? 
B. Exactly $\$ 102$
C. Less than $\$ 102$

2. If the interest rate on your savings account was $1 \%$ per year and inflation was $2 \%$ per year. After one year, how much would you be able to buy with the money on this account?

A. More than today

B. As much as today

C. Less than today

3. Please tell me whether this statement is true or false: "Buying a single company's stock usually provides a safer return than a stock mutual fund."

- True

- False

We define the three questions above as respectively: 1. compounded risk question, 2. real returns question, and 3.risk diversification question. It is standard in the literature to measure financial literacy both as the performance attained along the three questions altogether, and as the performance on each question individually considered (Lusardi and Mitchell, 2014).

In our sample 27 percent of scratch-off players answered correctly to all of the three financial questions, against 24 percent of slot/videopoker players (see Figure 1). The share rises to 37 percent among those not playing any of the considered games and 49 percent among those answering that they do not play scratch-off lotteries because it is not economically convenient. 
We can compare these shares with those from international surveys showing that the percent of those answering correctly to all of the three questions is 30 percent in the United States, 53 percent in Germany and 24.9 percent in Italy (Lusardi and Mitchell, 2014; Fornero and Monticone, 2011). Our findings also match well the outcome from the survey administered in Italy in 2011 by Fornero and Monticone since an online sample survey is expected to be upward biased in terms of education and young age, two characteristics associated with higher financial education in the literature (Lusardi and Mitchell. 2014). Hence it is reasonable that financial education is on average higher than in non online surveys ${ }^{5}$.

Shares on those answering correctly to all of the three questions are paralleled by an average number of correct answers of 1.8 among scratch-off players, 1.7 among slot/videopoker players, 2 among those not playing both games and 2.3 among those answering that they do not play scratch-off lotteries because it is not economically convenient.

Specific differences in the three questions are as follows. The compounded interest question is answered correctly by 74 percent of scratch-off players, 60 percent of slot/videopoker players, 81 percent of those not playing both and 88 percent among those answering that they do not play scratch-off lotteries because it is not economically convenient. Distances are much narrower on the real return question $(71,69,71$ and 81 percent respectively), while sharper on the mutual fund risk diversification question (39, 40, 50 and 66 percent respectively).

We may again compare these findings with the percent of correct answers to the three questions in Italy that is 40, 59.3 and 52.2 percent (Fornero and Monticone, 2011). Overall, our sample seems to overperform findings from the previous Italian study on the first two answers but not on the third answer.

\footnotetext{
${ }^{5}$ It would be possible in principle to provide weighted findings using weights of the population of gamblers. These weights are however unknown. It does not make sense to use the known Italian population weights given that gamblers have socio-demographic characteristics quite different from the Italian population.
} 
Hypothesis testing on the difference of financial education between players and non players finds in all cases significant results (Table 4). The share of those answering correctly all of the three questions is significantly different between scratch-off players and those not playing either scratch-off or slot/videopoker (Pearson $\chi^{2} 4.56$, p-value 0.033), between slot/videopoker players and those not playing either scratch-off or slot/videopoker (Pearson $\chi^{2} 5.40$, p-value 0.020) and between scratch-off players and those not playing scratch-off because not economically convenient (Pearson $\chi^{2} 14.30$, p-value 0.000). The differences among the three pairs of groups in terms of average number of correct questions are as well significant in the same direction (Table 4). Analyzing in detail the single questions we find that the significant difference is mainly driven by the first and third question (compounded interest and mutual fund/risk diversification), while there is no significant difference between players and non players in the second real return question.

We may therefore wonder, based on these findings, whether scratch-off and/or slot/videopoker players, even though being aware of buying a special asset satisfying their preferences of impatience and asymmetry, are aware of the risk that they are taking if they do not understand as correctly as non players how risk can be diversified and how financial value evolves over time.

\section{Econometric findings}

We test whether the negative nexus between playing slot/videopoker and financial education remains significant after controlling for standard sociodemographic factors.

We start by estimating the following model 
(1) SlotVideoPoker

$$
\begin{aligned}
& =\alpha_{0}+\alpha_{1} \text { FinEdu }_{i}+\alpha_{2} \text { Male }_{i}+\sum_{k} \gamma_{k} \text { DEducationLevel }_{k, i} \\
& +\sum_{l} \lambda_{l} \text { DIncomeClass }_{l, i}+\sum_{m} \vartheta_{m} \text { DWorkStatus }_{m, i}+\sum_{p} \eta_{p} \text { DArea }_{p, i}+\varepsilon_{i}
\end{aligned}
$$

where the dependent variable measures alternatively the intensity of slot/videopoker play or participation to slot/videopoker play. In the first case the variable assumes different categorical values corresponding to different levels of intensity $(0=$ never, $1=$ few times a year; $2=$ about once a month; $3=$ about once a week; $4=$ more than once a week; $5=$ about once a day; $6=$ up to 3 times a day; $7=$ more than 3 times a day) and the estimated model is an ordered logit. In the second case the variable is a (0/1) dummy taking value one if the respondent plays slot and/or videopoker and the estimated model is a logit. The financial education variable generically indicated as FinEdu is alternatively a dummy taking value one for those answering correctly to all of the three financial education questions (AllFEQuestionsCorrect), or the number of financial education questions answered correctly (NofCorrectFEQuestions).

In the specification we control for male gender, education degree, income level, employment status and respondents' geographical location. More in detail we consider the following classes of education (elementary school, middle school, high school, first level degree, second level degree, ${ }^{6}$ post-degree level), income (0-5,000€; 5,001-15,000€; 15,001-25,000€; 25,001-35,000€; 35,001-55,000€; 55,001-75,000€; 75,001-100,000€; 100,001-150,000€; above 150,000€), employment status (student, self-employed, employee, unemployed, retired) and geographical areas (North and South regions). The omitted baseline is the first category of each variable, and it is "Center" for geographical areas.

Most of these controls have been shown to matter in financial education. Males and more educated individuals have usually a higher financial education (Lusardi and Mitchell, 2014). This is also the case in

\footnotetext{
${ }^{6}$ The Italian University education system includes a first level three-year degree and a second level twoyear degree corresponding to the Master degree of the US-UK system.
} 
our sample where the difference is quite strong (41 percent of males answer correctly to all of the three questions against only 23 percent of females). Controlling for the gender dummy should therefore reinforce our effect since slot/videopoker players are more likely to be males in our sample. The opposite should occur for education since already in Table 1 slot/videopoker players and scratch-off players are relatively less educated, and school education is negatively correlated with financial education also in our sample (only 17.01 percent of those with no more than middle school education answer correctly to all of the three questions, against 33.24 percent of the complementary sample with higher education levels).

We as well know from the literature that individuals with a financial safety net are in general "more lazy" in getting informed and therefore have lower financial education (Lusardi and Mitchel, 2014 and Jappelli and Padula, 2013). This is confirmed in our sample where the level of financial education of retired workers is lower than that of self-employed. For this reason work status is expected to affect as well our findings.

Overall, these preliminary considerations tell us that the check on the nexus between financial education and gambling is quite severe since, with the exception of the gender dummy, inclusion of income, school education and work status controls should weaken the significance of the financial education variable given that the three groups of variables are all socio-demographic factors positively correlated with both gambling and lower financial education.

When estimating (1) we find that respondents who answer correctly to every question of financial education have a 7-8 percent lower probability of playing slot/videopoker according to the different specifications (Table 5). The gender effect is also very strong since males have a 18-20 percent lower probability of not playing slot/videopoker. Respondents with income between 100,000€ and 150,000€ have around 30 percent lower probability of participating. All employment status groups have a significantly higher probability of playing than the omitted benchmark of students. Education as well matters since the more (school) educated respondents have a higher probability of not playing. 
To test the nexus between participation to scratch-off lotteries and financial education we estimate the following model

(2) Scratch $_{i}=\alpha_{0}+\alpha_{1}$ FinEdu $_{i}+\alpha_{2}$ Male $_{i}+\sum_{k} \gamma_{k}$ DEducationLevel $_{k, i}$

$$
+\sum_{l} \lambda_{l} \text { DIncomeClass }_{l, i}+\sum_{m} \vartheta_{m} \text { DWorkStatus }_{m, i}+\sum_{p} \eta_{p} \text { DArea }_{\eta, i}+\varepsilon_{i}
$$

where the dependent variable is a $(0 / 1)$ dummy measuring participation to scratch-off lotteries, the financial education variable is, in turn, the correct answer to one of the three financial education questions and the other controls are as in (1). Findings from this estimate show that the significant financial education variable is the correct answer to the third (mutual funds/risk diversification) question that is related to an around 10 percent lower likelihood of participating to scratch-off lotteries after controlling for the other socio-demographic factors in the estimate (Table 6). Among other controls the unemployed have a 23-24 percent higher, while those having post-graduate education a 24-25 percent lower likelihood of participating. Respondents living in the North are also less likely to play (11-12 percent lower probability).

\subsection{Further comments and endogeneity issue}

Empirical findings shown so far do not measure causal relationships, but in this domain even significant correlation has a strong relevance and may be very telling as well. Since it is rather unlikely that an individual loses financial education by gambling, then the most likely nexus is that those who have relatively lower financial education are keener to gamble since they do not fully understand the implications of their choices on their financial wellbeing and stability. It is therefore obviously important to know whether higher financial education causes a reduction of bets in scratch-off lotteries and/or slot/videopoker tickets. As well it is however important to see that those who actually play have lower financial education and therefore are less endowed with competencies that are important, especially to them, to evaluate the consequences that their wins and losses have on their financial wellbeing. 
The existence of a clear-cut causality nexus from the regressor to the dependent variable would be however important for a second part of the policy conclusions. If the nexus exists then the clear policy advice is to invest in financial education in order to reduce the number of gamblers. Instrumental variable approaches looking at the causal nexus from this side could ascertain better whether the causality link exists.

Another indication going in the direction of the existence of a causality nexus lies in our group of respondents saying that it is not economically convenient to buy scratch-off lottery tickets. These respondents have much higher financial education as shown in Figure 1. This pattern of correlations seems to suggest that when individuals have more financial education they conclude that it is not economically convenient to buy scratch-off tickets.

In the estimate below we see whether financial education significantly affects the probability of "rational disapproval" (i.e."I do not play scratch-off lotteries because they are not economically convenient"). After controlling for gender, education, income, employment status, and geographical area, we find a strong and significant effect of financial education. Answering correctly to one more question of financial education raises by around 8 percent the probability of considering scratch-off tickets not economically convenient (Table 7). Answering correctly to the three financial education questions raises such probability of around 14 percent. As indicated in our financial education test the impact is mainly determined by questions 1 and 3. This seems to suggest that knowing both how a financial value evolves over time and about the possibility of risk diversification correlates with a lower probability of buying scratch-off tickets.

\section{Conclusions and policy implications}

Our empirical analysis investigates preferences, biases and financial education of two particular categories of players represented by individuals buying scratch-off lottery tickets and/or playing slot/videopoker. 
Our results show that scratchers overestimate the probability of winning at least the ticket price and have stronger preferences matching some specific characteristics of scratch-off tickets (relatively higher taste for asymmetry and higher impatience than non players) but have lower financial education (more specifically on the understanding of how economic value evolves over time and about risk diversification). We argue that these deficiencies may affect negatively their capacity of evaluating the impact of playing choices on their overall financial wellbeing. Our findings therefore indicate that scratching is both a matter of tastes and bias, and it is further associated with lower (risk diversification) financial literacy. The same relatively lower financial education is found in slot/videolottery players.

We are unable at present to establish whether the observed correlation hides a causality nexus where financial education discourages playing. We are inclined to think so given that individuals saying that they do not scratch because they consider it not economically convenient have a higher financial education than the rest of the sample. We as well remark that the simple correlation is already important per se and has clear-cut policy implications. Our findings document that scratch-off and/or slot/videopoker players are a fragile group with lower education and higher unemployment and retirement incidence. This group is relatively less equipped to evaluate consequences of their actions on their financial wellbeing. More financial education to them is therefore urgently needed. The belief of a causality nexus would imply a further policy consideration related to the possibility of a higher investment in financial education in order to discourage undertaking these two kinds of games. Results of our paper imply as well with their policy advice a potential trade-off for governments: will the latter be willing to provide more financial education to gamblers or would they be reluctant to do so not to reduce tax revenues from gambling? 
Table 1 Summary descriptive findings for players and non players

\begin{tabular}{|c|c|c|c|c|c|}
\hline & All sample & $\begin{array}{l}\text { Playing } \\
\text { slot/videopoker }\end{array}$ & $\begin{array}{l}\text { Buying } \\
\text { scratch-off } \\
\text { tickets }\end{array}$ & $\begin{array}{l}\text { Neither buying } \\
\text { scratch-off } \\
\text { tickets nor } \\
\text { playing } \\
\text { slot/videopoker }\end{array}$ & $\begin{array}{l}\text { Not } \\
\text { scratching } \\
\text { because not } \\
\text { economically } \\
\text { convenient }\end{array}$ \\
\hline Overall sample & $\sqrt{ }$ & 24.5 & 46.9 & 44.68 & 21.99 \\
\hline Male & 47 & 65.7 & 46.7 & 45.5 & 52.68 \\
\hline \multicolumn{6}{|c|}{ Within group education distribution } \\
\hline $\begin{array}{l}\text { Elementary } \\
\text { /middle school }\end{array}$ & 10.10 & 22.34 & 10.88 & 5.43 & 3.33 \\
\hline High school & 34.98 & 54.26 & 43.01 & 26.09 & 23.33 \\
\hline First level degree & 17.24 & 8.51 & 18.65 & 16.85 & 20 \\
\hline Second level degree & 20.20 & 11.70 & 16.06 & 26.63 & 23.33 \\
\hline Four years degree & 0.49 & 2.13 & & & 2.22 \\
\hline Post degree level & 17 & 1.06 & 11.4 & 25.00 & 27.28 \\
\hline \multicolumn{6}{|c|}{ Within group work status distribution } \\
\hline Student & 10.38 & 13 & 11.85 & 9.09 & 6.52 \\
\hline Self-employed & 44.44 & 46 & 44.3 & 44.91 & 48.9 \\
\hline Employee & 10.86 & 16 & 13.91 & 7.49 & 4.35 \\
\hline Unemployed & 10.63 & 15.23 & 13.7 & 7.4 & 4.30 \\
\hline Retired & 2.66 & 8 & 2. 06 & 0.53 & 0 \\
\hline \multicolumn{6}{|c|}{ Within group income distribution } \\
\hline $0.5,000 €$ & 20.10 & 18.68 & 16.67 & 22.46 & 18.68 \\
\hline $5,000-15,000 €$ & 22.72 & 28.43 & 22.33 & 22.45 & 27.47 \\
\hline $15,001-25,000 €$ & 29.18 & 30.39 & 34.01 & 24 & 23.07 \\
\hline $25,001-35,000 €$ & 14.11 & 13.72 & 13.2 & 15.5 & 15.38 \\
\hline $35,001-55,000 €$ & 7.89 & 3.92 & 7.1 & 9.09 & 7.69 \\
\hline $55,001-75,000 €$ & 3.34 & 4.90 & 3.55 & 2.67 & 4.39 \\
\hline $75,001-100,000 €$ & 1.43 & 0.98 & 0 & 2.67 & 1.09 \\
\hline $100,001-150,000 €$ & 0.7 & 0.98 & 0.5 & 0.54 & 2.20 \\
\hline More than $150,000 €$ & 0.47 & 0 & 0.5 & 0.54 & \\
\hline
\end{tabular}

Table 1 Summary descriptive findings for players and non players (follows)

\begin{tabular}{llllll}
\hline \hline All sample & $\begin{array}{l}\text { Playing } \\
\text { slot/videopoker }\end{array}$ & $\begin{array}{l}\text { Buying } \\
\text { scratch-off } \\
\text { tickets }\end{array}$ & $\begin{array}{l}\text { Neither buying } \\
\text { scratch-off } \\
\text { tickets nor } \\
\text { playing } \\
\text { slot/videopoker }\end{array}$ & $\begin{array}{l}\text { Not } \\
\text { scratching } \\
\text { because not } \\
\text { economically } \\
\text { convenient }\end{array}$ \\
\hline \multirow{2}{*}{ Elementary } & 37.89 & 57.14 & 41.9 & 30.65 & 27.18
\end{tabular}


/middle

school

High schoo

42.57

31.87

47.62

40.86

40.22

diploma

First level

4.20

1.10

5.3

3.76

3.26

degree

Second level $\quad 7.18$

5.49

4.2

10.21

13.04

degree

Four years $\quad 5.69$

2.20

0.53

10.75

14.13

degree

Post degree $\quad 2.47$

2.20

0.53

3.76

2.17

level

$\underline{\text { Within group father's education distribution }}$

Elementary $\quad 36.11$

52.29

37.96

32.44

31.53

/middle

school

High school $\quad 41.85$

36.36

45.99

39.46

34.78

First level

2.5

2.27

4.28

1.08

1.09

degree

Second level $\quad 7.77$

2.27

6.42

10.27

9.78

degree

Four years $\quad 9.27$

4.54

5.35

12.43

15.22

degree

Post degree $\quad 2.50$

2.27

4.32

7.6

level

Within group mother's work status distribution

Student $\quad 1.07$

2.54

0.02

9.60

Self-employed 8.24

8.86

7.95

8.47

8.99

Employee $\quad 45.48$

34.17

39.2

51.98

55.05

Unemployed 33.51

45.57

40.90

27.12

26.97

Retired

11.70

8.86

11.93

11.30

8.99

Within group father's work status distribution

Student

0.56

2.67

0.01

Self-employed 22.50

28

22.75

21.89

24.14

Employee

48.33

40

47.90

49.11

49.42 


\begin{tabular}{llllll} 
Unemployed & 13.33 & 13.33 & 13.17 & 14.79 & 13.79 \\
Retired & 15.28 & 16 & 16.17 & 14.20 & 12.64 \\
& \multicolumn{5}{c}{ Geographical distribution } \\
North & 39.47 & 46.66 & 37.06 & 37.57 & 43.01 \\
Centre & 35.46 & 30.48 & 36.04 & 36.51 & 31.18 \\
South & 15.60 & 10.48 & 14.72 & 18.52 & 21.51 \\
\hline \hline
\end{tabular}

Table 2 Descriptive findings on habits of players' and non players' groups

\begin{tabular}{|c|c|c|c|c|c|}
\hline & "All sample & $\begin{array}{l}\text { Playing } \\
\text { slot/videopoker }\end{array}$ & $\begin{array}{l}\text { Buying scratch- } \\
\text { off tickets }\end{array}$ & $\begin{array}{l}\text { Neither buying } \\
\text { scratch-off tickets } \\
\text { nor playing } \\
\text { slot/videopoker }\end{array}$ & $\begin{array}{l}\text { Not scratching } \\
\text { because not } \\
\text { economically } \\
\text { convenient }\end{array}$ \\
\hline $\begin{array}{r}\text { Fast food - less than } \\
\text { once a week }\end{array}$ & 90.32 & 85.57 & 89.23 & 92.02 & 87.91 \\
\hline $\begin{array}{r}\text { Fast food - more } \\
\text { than once a week }\end{array}$ & 9.68 & 14.43 & 10.77 & 7.98 & 12.09 \\
\hline $\begin{array}{l}\text { Alcoholic drinks - } \\
\text { less than once a week }\end{array}$ & 43.99 & 32.33 & 40.00 & 47.62 & 38.04 \\
\hline $\begin{array}{l}\text { Alcoholic drinks - } \\
\text { more than once a week }\end{array}$ & 56.01 & 67.67 & 60.00 & 52.38 & 61.96 \\
\hline $\begin{array}{r}\text { Super-alcoholic } \\
\text { drinks - less than once } \\
\text { a week }\end{array}$ & 73.99 & 64.29 & 69.74 & 26.06 & 69.23 \\
\hline $\begin{array}{r}\text { Super-alcoholic } \\
\text { drinks - more than } \\
\text { once a week }\end{array}$ & 26.01 & 35.71 & 30.26 & 23.94 & 30.77 \\
\hline $\begin{array}{r}\text { Tobacco- less than } \\
\text { once a week }\end{array}$ & 68.04 & 46.94 & 64.95 & 26.06 & 70.65 \\
\hline $\begin{array}{r}\text { Tobacco- more than } \\
\text { once a week. }\end{array}$ & 31.96 & 53.06 & 35.05 & 23.94 & 29.35 \\
\hline
\end{tabular}

Table 3 Biases and preferences of players vs non players

Panel A "Kanheman-Tversky" test on overestimation of winning probabilities

\begin{tabular}{|c|c|c|c|c|}
\hline $\begin{array}{l}\% \% \text { of } \\
\text { overestimating } \\
\text { scratchers }\end{array}$ & $\begin{array}{l}\% \text { of } \\
\text { overestim } \\
\text { ating non } \\
\text { scratchers }\end{array}$ & $\begin{array}{l}\text { Test Scratchers vs } \\
\text { non Scratchers }\end{array}$ & $\begin{array}{l}\text { Test Scratchers } \\
\text { vs non players to } \\
\text { both scratch-off } \\
\text { lotteries and } \\
\text { slot/videopoker }\end{array}$ & $\begin{array}{l}\text { Test Scratchers } \\
\text { vs those not } \\
\text { scratching } \\
\text { because not } \\
\text { economically } \\
\text { convenient }\end{array}$ \\
\hline
\end{tabular}




\begin{tabular}{lccccc}
\hline $\begin{array}{l}\text { Percent } \\
\text { overestimating } \\
\text { wins }\end{array}$ & & & & \\
1 euro ticket & 28.93 & 32.29 & $\begin{array}{l}0.5526 \\
(0.457)\end{array}$ & $(0.548)$ & 0.1531 \\
& & & & & $(0.696)$ \\
2 euro ticket & 36.04 & 29.15 & 2.2695 & 1.0048 & 2.3931 \\
& & & $(0.132)$ & $(0.316)$ & $(0.122)$ \\
3 euro ticket & 47.72 & 50.67 & 0.3659 & 2.0635 & 0.3840 \\
& & & $(0.545)$ & $(0.151)$ & $(0.535)$ \\
5 euro ticket & 57.87 & 51.57 & 1.6735 & 1.4102 & 1.0025 \\
& & & $(0.196)$ & $(0.235)$ & $(0.317)$ \\
10 euro ticket & 17.26 & 20.18 & 0.5842 & 0.9493 & 1.6592 \\
& & & $(0.445)$ & $(0.330)$ & $(0.198)$ \\
20 euro ticket & 45.18 & 48,43 & 0.4444 & 1.2190 & 1.0497 \\
& & & $(0.505)$ & $(0.270)$ & $(0.306)$ \\
\hline \hline
\end{tabular}

All tests are Pearson $\chi^{2}$ with p-values in round brackets.

The table indicates in the first two columns percent of respondents belonging to groups in column headers who overestimate jackpot winning probabilities. Data are driven from the question below

Please consider the scratch-off ticket with the highest jackpot for each category in first column. How often do you think it is possible to win the jackpot?

\begin{tabular}{|c|c|c|c|c|c|c|c|c|c|c|}
\hline & & $\begin{array}{l}\text { every } \\
5730 \\
\text { tickets }\end{array}$ & $\begin{array}{c}\text { every } \\
755000 \\
\text { tickets }\end{array}$ & $\begin{array}{c}\text { every } \\
1680000 \\
\text { tickets }\end{array}$ & $\begin{array}{c}\text { every } \\
1920000 \\
\text { tickets }\end{array}$ & $\begin{array}{c}\text { every } \\
3600000 \\
\text { tickets }\end{array}$ & $\begin{array}{c}\text { every } \\
4560000 \\
\text { tickets }\end{array}$ & $\begin{array}{c}\text { every } \\
2880000 \\
\text { tickets }\end{array}$ & $\begin{array}{c}\text { every } \\
15840000 \\
\text { tickets } \\
\end{array}$ & $\begin{array}{c}\text { every } \\
21830000 \\
\text { tickets } \\
\end{array}$ \\
\hline $1 €$ & tickets & & & & & & & & & \\
\hline $2 €$ & tickets & & & & & & & & & \\
\hline $3 €$ & tickets & & & & & & & & & \\
\hline $5 €$ & tickets & & & & & & & & & \\
\hline $10 €$ & tickets & & & & & & & & & \\
\hline $20 €$ & tickets & & & & & & & & & \\
\hline
\end{tabular}

$\underline{\text { Panel B test on underestimation of tickets needed to win at least the price ticket }}$

\begin{tabular}{|c|c|c|c|c|c|}
\hline & $\begin{array}{c}\% \text { of } \\
\text { underestimating } \\
\text { scratchers }\end{array}$ & $\begin{array}{l}\% \text { of } \\
\text { underestimating } \\
\text { non scratchers }\end{array}$ & $\begin{array}{l}\text { Test Scratchers } \\
\text { vs non } \\
\text { Scratchers }\end{array}$ & $\begin{array}{l}\text { Test Scratchers vs non } \\
\text { players to both scratch- } \\
\text { off lotteries and } \\
\text { slot/videopoker }\end{array}$ & $\begin{array}{l}\text { Test Scratchers } \\
\text { vs those not } \\
\text { scratching } \\
\text { because not } \\
\text { economically } \\
\text { convenient }\end{array}$ \\
\hline \multicolumn{6}{|l|}{$\begin{array}{l}\text { Percent } \\
\text { underestimating } \\
\text { wins }\end{array}$} \\
\hline 1 euro ticket & 24.87 & 21.08 & $0.85(0.355$ & $0.98(0.32)$ & $1.56(0.211)$ \\
\hline 2 euro ticket & 18.78 & 6.73 & 14.01) (0.00) & $9.73(0.002)$ & $7.63(0.006)$ \\
\hline 3 euro ticket & 11.17 & 3.14 & $10.488(0.001)$ & $7.733(0.005)$ & $5.058(0.025)$ \\
\hline 5 euro ticket & 10.66 & 2.24 & $12.763(0.00)$ & $9.862(0.002)$ & $4.599(0.032$ \\
\hline 10 euro ticket & 8.63 & 3.14 & $5.852(0.016)$ & $4.013(0.045)$ & $4.331(0.037)$ \\
\hline
\end{tabular}


All tests are Pearson $\chi^{2}$ with p-values in round brackets.

The table indicates in the first two columns percent of respondents belonging to groups in column headers who underestimate number of tickets needed to win the same amount of one ticket bought. Data are driven from the question below

Please consider the most favourable ticket for each category in the first column. How often do you think it is possible to win the same amount of the ticket bought?

Please mark one box per each row

\begin{tabular}{|c|c|c|c|c|c|c|c|c|c|}
\hline & & $\begin{array}{c}\text { every } 2-3 \\
\text { tickets }\end{array}$ & $\begin{array}{c}\text { every 4-6 } \\
\text { tickets }\end{array}$ & $\begin{array}{c}\text { every } 7-9 \\
\text { tickets }\end{array}$ & $\begin{array}{c}\text { every } 10-12 \\
\text { tickets }\end{array}$ & $\begin{array}{c}\text { every } 20-22 \\
\text { tickets }\end{array}$ & $\begin{array}{c}\text { every } 50-52 \\
\text { tickets }\end{array}$ & $\begin{array}{c}\text { every } 80-82 \\
\text { tickets }\end{array}$ & $\begin{array}{c}\text { every } 100 \text { - } 102 \\
\text { tickets }\end{array}$ \\
\hline $1 €$ & tickets & & & & & & & & \\
\hline $2 €$ & tickets & & & & & & & & \\
\hline $3 €$ & tickets & & & & & & & & \\
\hline $5 €$ & tickets & & & & & & & & \\
\hline $10 €$ & tickets & & & & & & & & \\
\hline $20 €$ & ticket & & & & & & & & \\
\hline
\end{tabular}

\section{$\underline{\text { Panel C Taste for asymmetry }}$}

$\begin{array}{llll}\begin{array}{l}\text { Scratch-off } \\ \text { players }\end{array} & \begin{array}{l}\text { Slot/videopoker } \\ \text { players }\end{array} & \begin{array}{l}\text { Non players } \\ \text { of both }\end{array} & \begin{array}{l}\text { Not playing scratch-off } \\ \text { because not ec. } \\ \text { convenient }\end{array} \\ (1) & (2) & (3) & \text { con }\end{array}$

(2)

52.89

11.63

35.48

(1) vs (2)

(1) vs (3)

$2.46(0.29)$
70.72

14.92

14.36
Lottery $2 \quad 16.28$

Lottery 3

23.83

Pearson $\chi^{2}$

(2) vs (3)

(p-value)

Legend: the table presents percent of respondents to each of the three choices in the question below for each group indicated in column headers

Among the 3 different tickets, which one would you buy?

Please mark one box

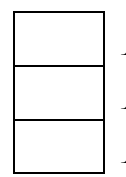

A $5 €$ ticket that offers 1 chance over 100 of winning $500 €$

A $5 €$ ticket that offers 1 chance over 1000 of winning $500 €$ and 1 chance over 1000 of winning $1.000 €$

A $5 €$ ticket that offers 1 chance over 1000 of winning $100 €$ e 1 chance over 5000000 of winning 1.000.000€

\section{$\underline{\text { Panel D Intertemporal preferences }}$}




$\begin{array}{cccc}\text { Scratch-off players } & \begin{array}{c}\text { Slot/videopoker } \\ \text { players }\end{array} & \begin{array}{c}\text { Non players } \\ \text { of both }\end{array} & \begin{array}{r}\text { Not playing } \\ \text { scratch-off } \\ \text { because not ec. } \\ \text { convenient }\end{array} \\ \text { (1) } & \text { (2) } & & \text { (3) }\end{array}$

(4)

$\begin{array}{lcccc}\text { Choice 1 } & 88.27 & 86.60 & 75 & 69.32 \\ \text { Choice 2 } & 2.04 & 2.06 & 6.11 & 4.55 \\ \text { Choice 3 } & 1.53 & 1.03 & 3.33 & 3.41 \\ \text { Choice 4 } & 3.06 & 3.09 & 3.89 & 5.68 \\ \text { Choice 5 } & 5.10 & 7.22 & 11.67 & 17.05 \\ \text { Pearson } \chi^{2} & (1) \text { vs (3) } & (2) \text { vs (3) } & & (1) \text { vs (4) } \\ \text { (p-value) } & 12.27(0.015) & 5.94(0.203) & & 15.93(0.003)\end{array}$

Legend: the table presents percent of respondents to each of the four choices in the question below for each group indicated in column headers

Which one of the following combinations between time and money would you prefer?

Please mark one box

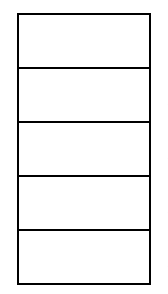

$100 €$ immediately

Notbing now but $101 €$ after one month

Nothing now but 106,15€ after 6 months

Nothing now but 112,7€ after a year

Notbing now but $127 €$ after 2 years

\section{Figure 1 Financial education and gambling groups}

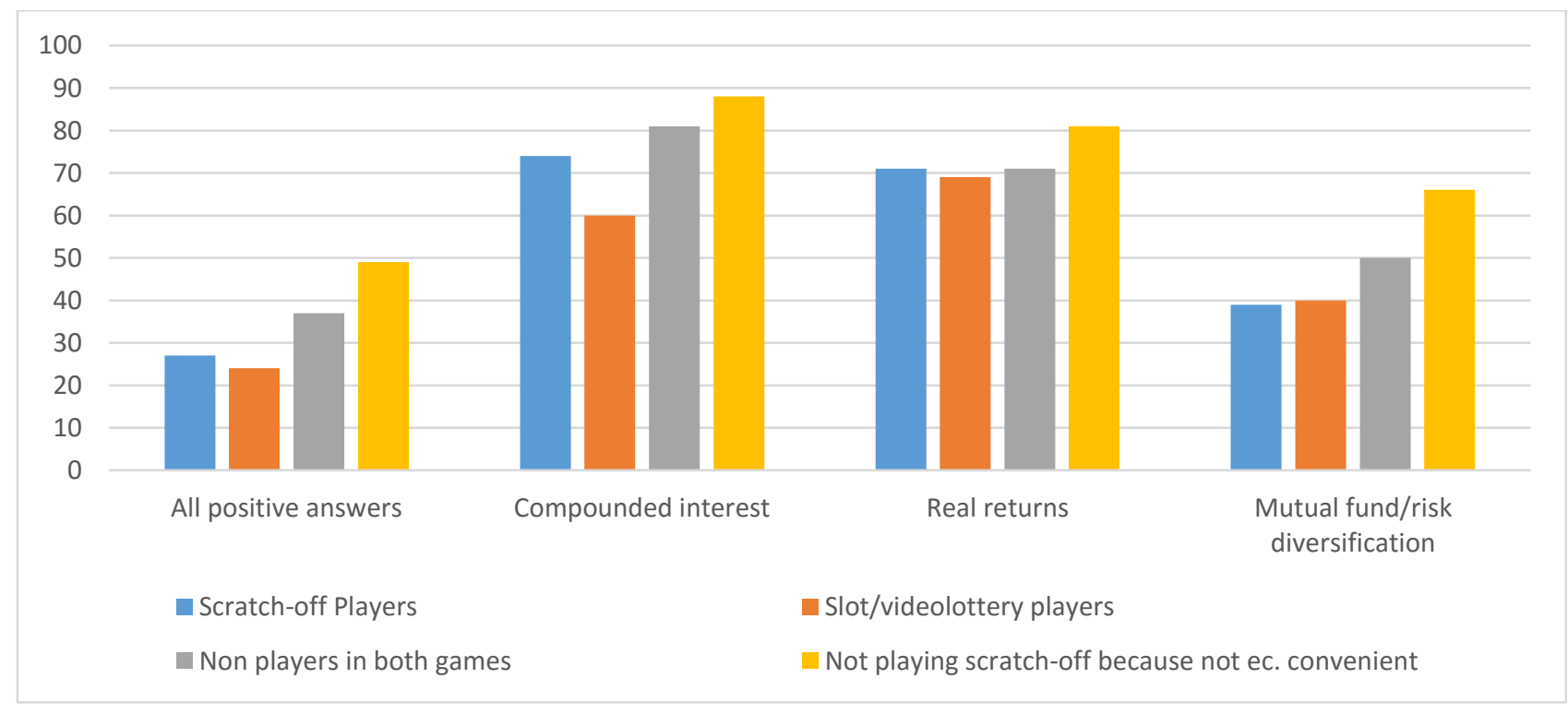

Vertical axis: percent of positive answers 
Table 4 Hypothesis testing on financial education and gambling groups

\begin{tabular}{|c|c|c|c|}
\hline & $\begin{array}{l}\text { Scratchers vs non } \\
\text { players of both }\end{array}$ & $\begin{array}{l}\text { Slot/videoplayers vs } \\
\text { non players of both }\end{array}$ & $\begin{array}{l}\text { Scratchers vs those } \\
\text { that do not scratch } \\
\text { because not ec. } \\
\text { convenient }\end{array}$ \\
\hline $\begin{array}{l}\text { All three questions } \\
\text { correct }\end{array}$ & $\begin{array}{ll}4.5622 & (0.033)\end{array}$ & $\begin{array}{ll}5.3998 \quad(0.020) \\
\end{array}$ & $14.2992 \quad(0.000)$ \\
\hline $\begin{array}{l}\text { Compounded } \\
\text { interest }\end{array}$ & $3.4284 \quad(0.064)$ & $16.1130 \quad(0.000)$ & $\begin{array}{ll}7.8846 \quad(0.005) \\
\end{array}$ \\
\hline Real return & $0.0355 \quad(0.851)$ & $0.2645 \quad(0.607)$ & $3.3237 \quad(0.068)$ \\
\hline $\begin{array}{l}\text { Mutual fund/risk } \\
\text { diversification }\end{array}$ & $4.8789 \quad(0.027)$ & $2.8580 \quad(0.091)$ & $11.3591 \quad(0.001)$ \\
\hline $\begin{array}{l}\text { Avg. number of } \\
\text { correct questions }\end{array}$ & $2.0820(0.038)$ & $2.9651(0.003)$ & 3.9647 (0.0001) \\
\hline
\end{tabular}

Pearson $\chi^{2}$ ( $\mathrm{p}$-values in round brackets) except for the last row (t-statistic)

Table 5 Financial education and gambling:econometric findings (marginal effects)

\begin{tabular}{lcccc}
\hline \hline VARIABLES & $(1)$ & $(2)$ & $(3)$ & $(4)$ \\
\hline \multirow{2}{*}{ NofCorrectFEQuestions } & $0.040^{* *}$ & & $0.043^{* *}$ & \\
& $(0.016)$ & & $(0.019)$ & \\
Male & $-0.207^{* * *}$ & $-0.205^{* * *}$ & $-0.183^{* * *}$ & $-0.182^{* * *}$ \\
& $(0.032)$ & $(0.031)$ & $(0.036)$ & $(0.036)$ \\
Self-Employed & $-0.184^{* * *}$ & $-0.192^{* * *}$ & $-0.196^{* * *}$ & $-0.196^{* * *}$ \\
& $(0.060)$ & $(0.060)$ & $(0.066)$ & $(0.066)$ \\
Employee & $-0.176^{* * *}$ & $-0.170^{* * *}$ & $-0.178^{* * *}$ & $-0.171^{* * *}$ \\
& $(0.046)$ & $(0.046)$ & $(0.051)$ & $(0.050)$ \\
Unemployed & $-0.200^{* * *}$ & $-0.192^{* * *}$ & $-0.200^{* * *}$ & $-0.191^{* * *}$ \\
& $(0.054)$ & $(0.054)$ & $(0.062)$ & $(0.062)$ \\
Retired & $-0.311^{* * *}$ & $-0.332^{* * *}$ & $-0.254^{* *}$ & $-0.258^{* *}$ \\
& $(0.094)$ & $(0.091)$ & $(0.111)$ & $(0.109)$ \\
$5.001-15.000 €$ & -0.063 & -0.063 & $-0.100^{*}$ & $-0.099^{*}$ \\
& $(0.050)$ & $(0.050)$ & $(0.057)$ & $(0.057)$ \\
15.001 - 25.000€ & -0.044 & -0.057 & -0.037 & -0.041 \\
& $(0.052)$ & $(0.052)$ & $(0.060)$ & $(0.060)$ \\
$25.001-35.000 €$ & 0.059 & 0.039 & 0.054 & 0.043 \\
& $(0.061)$ & $(0.060)$ & $(0.072)$ & $(0.071)$ \\
$35.001-55.000 €$ & 0.004 & -0.010 & 0.038 & 0.026 \\
& $(0.081)$ & $(0.081)$ & $(0.098)$ & $(0.098)$
\end{tabular}




\begin{tabular}{|c|c|c|c|c|}
\hline $55.001-75.000 €$ & $\begin{array}{l}-0.123 \\
(0.082)\end{array}$ & $\begin{array}{l}-0.125 \\
(0.081)\end{array}$ & $\begin{array}{c}-0.117 \\
(0.111)\end{array}$ & $\begin{array}{c}-0.112 \\
(0.110)\end{array}$ \\
\hline \multirow[t]{2}{*}{$75.001-100.000 €$} & 1.460 & 1.607 & -0.000 & -0.005 \\
\hline & (195.004) & (444.711) & $(0.162)$ & $(0.163)$ \\
\hline \multirow[t]{2}{*}{$100.001-150.000 €$} & $-0.246^{*}$ & $-0.261 *$ & $-0.344 * *$ & $-0.347 * *$ \\
\hline & $(0.134)$ & $(0.135)$ & $(0.174)$ & $(0.174)$ \\
\hline \multirow[t]{2}{*}{ More than $150.000 €$} & 1.414 & 1.524 & & \\
\hline & $(272.812)$ & $(667.703)$ & & \\
\hline \multirow[t]{2}{*}{ High school } & 0.056 & 0.067 & 0.058 & 0.066 \\
\hline & $(0.048)$ & $(0.047)$ & $(0.056)$ & $(0.055)$ \\
\hline \multirow[t]{2}{*}{ First level degree } & $0.145^{* *}$ & $0.158^{* *}$ & $0.219^{* * *}$ & $0.230 * * *$ \\
\hline & $(0.061)$ & $(0.061)$ & $(0.071)$ & $(0.071)$ \\
\hline \multirow[t]{2}{*}{ Second level degree } & $0.216^{* * *}$ & $0.238 * * *$ & $0.223 * * *$ & $0.242^{* * *}$ \\
\hline & $(0.056)$ & $(0.055)$ & $(0.063)$ & $(0.062)$ \\
\hline \multirow[t]{2}{*}{ 4-years degree (V.O) } & -0.174 & -0.178 & & \\
\hline & $(0.148)$ & $(0.150)$ & & \\
\hline \multirow[t]{2}{*}{ Post degree level } & 1.591 & 1.757 & $0.527 * * *$ & $0.539 * * *$ \\
\hline & $(57.348)$ & $(128.224)$ & $(0.128)$ & $(0.129)$ \\
\hline \multirow[t]{2}{*}{ North } & 0.013 & 0.018 & 0.038 & 0.037 \\
\hline & $(0.036)$ & $(0.035)$ & $(0.040)$ & $(0.040)$ \\
\hline \multirow[t]{2}{*}{ South } & 0.059 & 0.052 & 0.082 & 0.071 \\
\hline & $(0.052)$ & $(0.053)$ & $(0.062)$ & $(0.062)$ \\
\hline \multirow[t]{2}{*}{ AllFEQuestionsCorrect } & & $0.074 * *$ & & $0.078^{*}$ \\
\hline & & $(0.036)$ & & $(0.041)$ \\
\hline LR $\chi^{2}$ (p-value) & $154.0(0.00)$ & $152.1(0.00)$ & $129.7(0.00)$ & $128.2(0.00)$ \\
\hline Observations & 378 & 378 & 397 & 397 \\
\hline
\end{tabular}

Standard errors in parentheses. ${ }^{* * *} \mathrm{p}<0.01,{ }^{*} \mathrm{p}<0.05, * \mathrm{p}<0.1$. First and second column dependent variable: slot/videopoker playing intensity $(0=$ never, $1=$ few times a year; $2=$ about once a month; $3=$ about once a week; $4=$ more than once a week; $5=$ about once a day; $6=$ up to 3 times a day; $7=$ more than 3 times a day) ordered logit estimate. Third and fourth column dependent variable: (0/1) slot/videopoker play dummy - logit estimate. AllFEQUestionsCorrect: individuals answering correctly to all of the three financial education questions. NofCorrectFEQuestions: number of financial education questions answered correctly. Omitted benchmarks: student, 0-5,000€, elementary/middle school.

Table 6 Scratch-off lottery participation and financial education (logit estimate, marginal effects)

\begin{tabular}{lccc}
\hline VARIABLES & $(1)$ & $(2)$ & $(3)$ \\
\hline \multirow{2}{*}{ CompoundedInterestCorrect } & -0.024 & & \\
& $(0.059)$ & & \\
Male & -0.009 & -0.013 & 0.002 \\
& $(0.050)$ & $(0.051)$ & $(0.050)$ \\
Self-Employed & $0.221^{* *}$ & $0.223^{* *}$ & $0.215^{* *}$ \\
& $(0.093)$ & $(0.093)$ & $(0.093)$ \\
Employee & 0.068 & 0.068 & 0.071 \\
& $(0.066)$ & $(0.066)$ & $(0.066)$
\end{tabular}




\begin{tabular}{|c|c|c|c|}
\hline Unemployed & $\begin{array}{c}0.244 * * * \\
(0.086)\end{array}$ & $\begin{array}{c}0.242 * * * \\
(0.086)\end{array}$ & $\begin{array}{c}0.233 * * * \\
(0.086)\end{array}$ \\
\hline \multirow[t]{2}{*}{ Retired } & -0.070 & -0.061 & -0.066 \\
\hline & $(0.176)$ & $(0.176)$ & $(0.175)$ \\
\hline \multirow[t]{2}{*}{$5.001-15.000 €$} & 0.055 & 0.052 & 0.056 \\
\hline & $0.221 * * *$ & $0.219 * * *$ & $0.228 * * *$ \\
\hline \multirow[t]{2}{*}{$15.001-25.000 €$} & $(0.076)$ & $(0.076)$ & $(0.076)$ \\
\hline & 0.041 & 0.039 & 0.048 \\
\hline \multirow[t]{2}{*}{$25.001-35.000 €$} & $(0.092)$ & $(0.092)$ & $(0.092)$ \\
\hline & 0.070 & 0.067 & 0.075 \\
\hline \multirow[t]{2}{*}{$35.001-55.000 €$} & $(0.105)$ & $(0.105)$ & $(0.104)$ \\
\hline & 0.185 & 0.188 & 0.183 \\
\hline \multirow[t]{2}{*}{$55.001-75.000 €$} & $(0.148)$ & $(0.148)$ & $(0.145)$ \\
\hline & $0.221 * * *$ & $0.219 * * *$ & $0.228^{* * *}$ \\
\hline \multirow{2}{*}{$100.001-150.000 €$} & -0.009 & -0.020 & 0.011 \\
\hline & $(0.287)$ & $(0.287)$ & $(0.282)$ \\
\hline \multirow[t]{2}{*}{ More than $150.000 €$} & 0.058 & 0.071 & 0.068 \\
\hline & $(0.324)$ & $(0.324)$ & $(0.325)$ \\
\hline \multirow[t]{2}{*}{ High school } & 0.073 & 0.067 & 0.068 \\
\hline & $(0.095)$ & (0.094) & (0.094) \\
\hline \multirow{2}{*}{ First level degree } & 0.049 & 0.041 & 0.049 \\
\hline & $(0.106)$ & $(0.105)$ & $(0.105)$ \\
\hline \multirow[t]{2}{*}{ Second level degree } & -0.149 & -0.161 & -0.161 \\
\hline & $(0.104)$ & $(0.101)$ & $(0.101)$ \\
\hline \multirow[t]{2}{*}{ Post-degree level } & $-0.242 * *$ & $-0.252^{* *}$ & $-0.244^{* *}$ \\
\hline & $(0.106)$ & $(0.105)$ & $(0.104)$ \\
\hline \multirow[t]{2}{*}{ North } & $-0.114^{* *}$ & $-0.114 * *$ & $-0.119 * *$ \\
\hline & $(0.056)$ & $(0.056)$ & $(0.055)$ \\
\hline \multirow[t]{2}{*}{ South } & -0.068 & -0.065 & -0.068 \\
\hline & $(0.072)$ & $(0.073)$ & $(0.072)$ \\
\hline \multirow[t]{2}{*}{ RealReturnCorrect } & & 0.014 & \\
\hline & & $(0.054)$ & \\
\hline RiskDiversificationCorrect & & & $\begin{array}{c}-0.102 * * \\
(0.048)\end{array}$ \\
\hline LR $\chi^{2}$ (p-value) & $44.5(0.00)$ & $44.4(0.00)$ & $48.8(0.00)$ \\
\hline Observations & 392 & 392 & 392 \\
\hline
\end{tabular}

Standard errors in parentheses. ${ }^{* * *} \mathrm{p}<0.01,{ }^{* *} \mathrm{p}<0.05,{ }^{*} \mathrm{p}<0.1$. Dependent variable: $(0 / 1)$ scratch-off play dummy. Logit estimate. Omitted benchmarks: student, 75,000-100,000€, elementary/middle school.

Table 7 Financial education and gambling "rational disapproval" (marginal effects)

\begin{tabular}{lccccc}
\hline \hline VARIABLES & $(1)$ & $(2)$ & $(3)$ & $(4)$ & $(5)$ \\
\hline \multirow{2}{*}{ NofCorrectFEQuestions } & $0.079^{* * *}$ & & & & \\
& $(0.022)$ & & & & \\
Male & 0.049 & 0.054 & $0.069^{*}$ & 0.064 & 0.055 \\
& $(0.040)$ & $(0.040)$ & $(0.040)$ & $(0.040)$ & $(0.040)$ \\
Self-Employed & $-0.185^{* *}$ & $-0.191 * *$ & $-0.173^{* *}$ & $-0.189 * *$ & $-0.179 * *$ \\
& $(0.079)$ & $(0.079)$ & $(0.080)$ & $(0.080)$ & $(0.080)$ \\
Employee & -0.075 & -0.075 & -0.060 & -0.074 & -0.065 \\
& $(0.051)$ & $(0.051)$ & $(0.051)$ & $(0.052)$ & $(0.051)$
\end{tabular}




\begin{tabular}{|c|c|c|c|c|c|}
\hline Unemployed & $\begin{array}{c}-0.277 * * * \\
(0.093)\end{array}$ & $\begin{array}{c}-0.275^{* * *} \\
(0.094)\end{array}$ & $\begin{array}{c}-0.287 * * * \\
(0.094)\end{array}$ & $\begin{array}{c}-0.275^{* * *} \\
(0.095)\end{array}$ & $\begin{array}{c}-0.265^{* * *} \\
(0.094)\end{array}$ \\
\hline \multirow[t]{2}{*}{$5.001-15.000 €$} & 0.056 & 0.057 & 0.062 & 0.062 & 0.051 \\
\hline & $(0.060)$ & $(0.060)$ & $(0.061)$ & $(0.061)$ & $(0.061)$ \\
\hline \multirow[t]{2}{*}{$15.001-25.000 €$} & $-0.123^{*}$ & $-0.121 *$ & $-0.113^{*}$ & $-0.114 *$ & $-0.129 *$ \\
\hline & 0.011 & 0.014 & 0.027 & 0.025 & 0.009 \\
\hline \multirow[t]{2}{*}{$25.001-35.000 €$} & $(0.073)$ & $(0.073)$ & $(0.073)$ & $(0.073)$ & $(0.073)$ \\
\hline & -0.059 & -0.062 & -0.036 & -0.042 & -0.053 \\
\hline \multirow[t]{2}{*}{$35.001-55.000 €$} & $(0.084)$ & $(0.085)$ & $(0.083)$ & $(0.084)$ & $(0.084)$ \\
\hline & 0.002 & 0.017 & 0.015 & -0.011 & -0.017 \\
\hline \multirow[t]{2}{*}{$55.001-75.000 €$} & $(0.115)$ & $(0.116)$ & $(0.121)$ & $(0.119)$ & $(0.116)$ \\
\hline & -0.068 & -0.051 & -0.063 & -0.077 & -0.041 \\
\hline \multirow[t]{2}{*}{$75.001-100.000 €$} & $(0.167)$ & $(0.166)$ & $(0.172)$ & $(0.173)$ & $(0.167)$ \\
\hline & 0.124 & 0.140 & 0.150 & 0.158 & 0.157 \\
\hline \multirow[t]{2}{*}{$100.001-150.000 €$} & $(0.188)$ & $(0.193)$ & $(0.189)$ & (0.191) & $(0.191)$ \\
\hline & 0.011 & 0.014 & 0.027 & 0.025 & 0.009 \\
\hline \multirow[t]{2}{*}{ High school } & 0.068 & 0.077 & 0.060 & 0.077 & 0.093 \\
\hline & $(0.115)$ & $(0.114)$ & $(0.116)$ & $(0.116)$ & $(0.114)$ \\
\hline \multirow[t]{2}{*}{ First level degree } & 0.167 & 0.179 & 0.165 & 0.185 & 0.188 \\
\hline & $(0.118)$ & $(0.118)$ & $(0.120)$ & $(0.119)$ & $(0.118)$ \\
\hline \multirow[t]{2}{*}{ Second level degree } & 0.174 & $0.192^{*}$ & 0.148 & 0.191 & $0.210^{*}$ \\
\hline & $(0.116)$ & $(0.116)$ & $(0.119)$ & $(0.117)$ & $(0.116)$ \\
\hline \multirow[t]{2}{*}{ Post-degree level } & $0.282^{* *}$ & $0.285^{* *}$ & $0.273^{* *}$ & $0.303^{* * *}$ & $0.311^{* * *}$ \\
\hline & $(0.114)$ & $(0.115)$ & $(0.116)$ & $(0.116)$ & $(0.114)$ \\
\hline \multirow[t]{2}{*}{ North } & $0.172 * * *$ & $0.178^{* * *}$ & $0.163^{* * *}$ & $0.169 * * *$ & $0.170 * * *$ \\
\hline & $(0.044)$ & $(0.045)$ & $(0.044)$ & $(0.045)$ & $(0.045)$ \\
\hline \multirow[t]{2}{*}{ South } & $0.139 * * *$ & $0.130^{* *}$ & $0.132^{* *}$ & $0.137^{* *}$ & $0.125^{* *}$ \\
\hline & $(0.053)$ & $(0.053)$ & $(0.054)$ & $(0.055)$ & $(0.054)$ \\
\hline AllFEQuestionsCorrect & & $\begin{array}{c}0.137^{* * *} \\
(0.039)\end{array}$ & & & \\
\hline CompoundedInterestCorrect & & & $0.137 * *$ & & \\
\hline \multirow[t]{2}{*}{ RealReturnCorrect } & & & & 0.078 & \\
\hline & & & & $(0.048)$ & \\
\hline \multirow[t]{2}{*}{ RiskDiversificationCorrect } & & & & & $0.118^{* * *}$ \\
\hline & & & & & $(0.038)$ \\
\hline $\mathrm{LR} \chi^{2}$ (p-value) & $67.9(0.00)$ & $66.6(0.00)$ & $62.0(0.00)$ & $57.9(0.00)$ & $64.3(0.00)$ \\
\hline Observations & 386 & 386 & 386 & 386 & 386 \\
\hline
\end{tabular}

Standard errors in parentheses. ${ }^{* * *} \mathrm{p}<0.01,{ }^{* *} \mathrm{p}<0.05,{ }^{*} \mathrm{p}<0.1$. Dependent variable: $(0 / 1)$ dummy with value one for those not playing scratch-off lotteries because not economically convenient. Omitted benchmarks: student, 0-5,000€, elementary/middle school. 



\section{References}

Barnes, G. M., Welte, J. W., Hoffman, J. H., \& Dintcheff, B. A. (1999). Gambling and alcohol use among youth: Influences of demographic, socialization, and individual factors. Addictive Behaviors, 24(6), 749-767.

Clarke, D. (2005). Motivational differences between slot machine and lottery players. Psychological Reports, Vol. 96 No.3, pp. 843-848.

Clotfelter, C. T., \& Cook, P. J. (1991). Selling hope: State lotteries in America. Harvard University Press

Cote, D., Caron, A., Aubert, J., Desrochers, V., and Ladouceur, R. (2003). Near wins prolong gambling on a video lottery terminal. Journal of Gambling Studies, Vol. 19 No. 4, pp. 433-438.

Delfabbro, P. H., and Winefield, A. H. (2000). Predictors of irrational thinking in regular slot machine gamblers, Journal of Psychology, Vol. 134 No. 2, pp. 117-128.

Dixon MJ, Collins K, Harrigan KA, Graydon C, Fugelsang JA.(2015) "Using sound to unmask losses disguised as wins in multiline slot machines", Journal of Gambling Studies

European State Lotteries and Toto Association (2011). European Lotteries' report on Lotteries in the EU and in Europe in 2011.

European Commission, GREEN PAPER On on-line gambling in the Internal Market $/ *$ COM/2011/0128 final $* /$

European Commission. (2015). Initiatives on the gambling market.

Fang, X., and Mowen, J. G. (2009). Examining the trait and functional motive antecedents of four gambling activities: Slot machines, skilled card games, sports betting, and promotional games. Journal of Consumer Marketing, Vol. 26 No. 2, pp. 121-131.

Fischer, S., \& Smith, G. T. (2008). Binge eating, problem drinking, and pathological gambling: Linking behavior to shared traits and social learning. Personality and individual Differences, 44(4), 789-800.

Fornero E, Monticone C, (2011). Financial Literacy and Pension Plan Participation in Italy. Netspar Discussion Paper No. 01/2011-019

French, M. T., Maclean, J. C., \& Ettner, S. L. (2008). Drinkers and bettors: Investigating the complementarity of alcohol consumption and problem gambling. Drug and alcohol dependence, 96(1), 155164.

Friedman, M., \& Savage, L. J. (1948). The utility analysis of choices involving risk. The journal of political economy, 279-304.

Garrett, T. A., \& Sobel, R. S. (1999). Gamblers favor skewness, not risk: Further evidence from United States' lottery games. Economics Letters, 63(1), 85-90.

Gilovich, T. (1983). Biased evaluation and persistence in gambling. Journal of personality and social psychology, 44(6), 1110.

Griffiths, M., (1997). The National Lottery and instant scratchcards: A psychological perspective. The Psychologist: The Bulletin of the British Psychological Society, 10, 26-29.

Griffiths, M., Scarfe, A., \& Bellringer, P. (1999). The UK national telephone gambling helpline- Results on the first year of operation. Journal of Gambling Studies, 15(1), 83-90.

Griffiths, M. (2000). Scratchcard gambling among adolescent males. Journal of Gambling Studies, 16(1), 79-91.

Griffiths, M., \& Wood, R. (2001). The psychology of lottery gambling. International gambling studies, $1(1), 27-45$.

Griffiths, M. (2002). Are lottery scratchcards a "hard" form of gambling?. Journal of Gambling Issues. 
Guryan, J., \& Kearney, M. S. (2008). Gambling at lucky stores: Empirical evidence from state lottery sales. The American Economic Review, 98(1), 458-473.

Hendriks, V. M., Meerkerk, G. J., OERS, H. A., \& Garretsen, H. F. (1997). The Dutch instant lottery: prevalence and correlates of at-risk playing. Addiction, 92(3), 335-346.

Jappelli T., Padula M. (2013). Investment in Financial Literacy and Social Security and Portfolio Choice. Centre for Studies in Economics and Finance.

Jensen C, Dixon M.J., Harrigan K.A, Sheepy E., Fugelsang J.A., Jarick M. (2013) Misinterpreting winning in multiline slot machine games. International Gambling Studies, vol. 13, issue 1, pages 112-126

Kahneman, D., \& Tversky, A. (1979). Prospect theory: An analysis of decision under risk. Econometrica: Journal of the Econometric Society, 263-291.

Langer, E. J. (1975). The illusion of control. Journal of personality and social psychology, 32(2), 311.

Lusardi A., Mitchell O.S. (2014). Financial Literacy around the World: An Overview. Journal of Pension Economics and Finance, 10(4): 497-508.

Nordmyr, J., Forsman, A. K., Wahlbeck, K., Björkqvist, K., \& Österman, K. (2014). Associations between problem gambling, socio-demographics, mental health factors and gambling type: sex differences among Finnish gamblers. International Gambling Studies, 14(1), 39-52.

Parker, J. D., Taylor, R. N., Eastabrook, J. M., Schell, S. L., \& Wood, L. M. (2008). Problem gambling in adolescence: Relationships with internet misuse, gaming abuse and emotional intelligence. Personality and Individual Differences, 45(2), 174-180.

Philander, K. S., \& MacKay, T. L. (2014). Online gambling participation and problem gambling severity: is there a causal relationship?. International Gambling Studies, 14(2), 214-227.

Quiggin, J. (1991). On the optimal design of lotteries. Economica, 1-16.

Shepherd, R. M., Ghodse, H., \& London, M. (1998). A pilot study examining gambling behaviour before and after the launch of the National Lottery and scratch cards in the UK. Addiction Research, 6(1), 5-12.

Stearns, J. M., \& Borna, S. (1995). The ethics of lottery advertising: Issues and evidence. Journal of Business Ethics, 14(1), 43-51.

Stewart, I. (1996). It probably won't be you. The Times Higher Educational Supplement, 14.

Tversky, A., \& Kahneman, D. (1971). Belief in the law of small numbers. Psychological bulletin, 76(2), 105.

Tversky, A., \& Kahneman, D. (1973). Availability: A heuristic for judging frequency and probability. Cognitive psychology, 5(2), 207-232.

Volberg, R. A., Abbott, M. W., Rönnberg, S., \& Munck, I. M. (2001). Prevalence and risks of pathological gambling in Sweden. Acta Psychiatrica Scandinavica, 104(4), 250-256.

Walker, M. B. (1992). The psychology of gambling. Pergamon Press.

Wood, R. T., \& Griffiths, M. D. (2004). Adolescent lottery and scratchcard players: Do their attitudes influence their gambling behaviour?. Journal of Adolescence, 27(4), 467-475. 


\section{Appendix}

Table A1 Summary statistics for the entire sample of scratch-off tickets sold in Italy

\begin{tabular}{|c|c|c|c|c|c|c|c|c|c|c|c|}
\hline $\begin{array}{l}\text { Scratch-off } \\
\text { ticket }\end{array}$ & $\begin{array}{l}\text { Ticket } \\
\text { Price }\end{array}$ & $\begin{array}{c}\text { Total } \\
\text { Revenue }\end{array}$ & $\begin{array}{l}\text { Player's } \\
\text { expected } \\
\text { gain } \\
\text { from the } \\
\text { jackpot }\end{array}$ & $\begin{array}{c}\text { Player's } \\
\text { expected gain } \\
\text { from the } \\
\text { jackpot ( } \% \\
\text { price) }\end{array}$ & $\begin{array}{l}\text { Total } \\
\text { expected } \\
\text { gain from } \\
\text { the ticket }\end{array}$ & $\begin{array}{l}\text { Players' net } \\
\text { loss (in } \\
\text { euro) }\end{array}$ & $\begin{array}{l}\text { Players' net loss } \\
\text { (\% price) }\end{array}$ & $\begin{array}{l}\text { Kurtosis } \\
\text { (gambling } \\
\text { odds) }\end{array}$ & $\begin{array}{c}\text { Skewness } \\
\text { (gambling } \\
\text { odds) }\end{array}$ & $\begin{array}{c}\text { Kurtosis of } \\
\text { prizes }\end{array}$ & $\begin{array}{c}\text { Skewness } \\
\text { of prizes }\end{array}$ \\
\hline Portafortuna & $1.0 €$ & $5.20 \mathrm{E}+07$ & 0.00329 & $0.33 \%$ & 0.590 & 0.41004 & $41.00 \%$ & 5.018 & 2.235 & 8.939 & 2.987 \\
\hline $\begin{array}{l}\text { Sette e } \\
\text { mezzo }\end{array}$ & $1.0 €$ & $5.80 \mathrm{E}+07$ & 0.0094 & $0.94 \%$ & 0.540 & 0.46002 & $46.00 \%$ & 4.492 & 2.181 & 8.751 & 2.948 \\
\hline $\begin{array}{l}\text { Super } \\
\text { settimana }\end{array}$ & $1.0 €$ & $5.00 \mathrm{E}+07$ & 0.12046 & $12.05 \%$ & 0.600 & 0.40037 & $40.04 \%$ & 7.102 & 2.616 & 8.999 & 3.000 \\
\hline 2016 & $1.0 €$ & $5.00 \mathrm{E}+07$ & 0.00595 & $0.60 \%$ & 0.660 & 0.33988 & $33.99 \%$ & 6.264 & 2.459 & 7.944 & 2.816 \\
\hline Fai 7 & $1.0 €$ & $3.80 \mathrm{E}+07$ & 0.00948 & $0.95 \%$ & 0.540 & 0.4596 & $45.96 \%$ & 4.492 & 2.181 & 8.751 & 2.948 \\
\hline 2015 & $1.0 €$ & $1.00 \mathrm{E}+07$ & 0.01389 & $1.39 \%$ & 0.612 & 0.38778 & $38.78 \%$ & 2.033 & 1.657 & 7.944 & 2.816 \\
\hline $\begin{array}{l}\text { Nuovo } \\
\text { turista } \times 10 \\
\text { anni }\end{array}$ & $2.0 €$ & $9.80 \mathrm{E}+07$ & 0.06247 & $3.12 \%$ & 1.298 & 0.7017 & $35.09 \%$ & 4.573 & 2.098 & 8.000 & 2.828 \\
\hline $\begin{array}{l}\text { Mi sento } \\
\text { fortunato }\end{array}$ & $2.0 €$ & $7.70 \mathrm{E}+07$ & 0.02083 & $1.04 \%$ & 1.293 & 0.7075 & $35.38 \%$ & 7.326 & 2.680 & 5.042 & 2.273 \\
\hline $\begin{array}{l}\text { Nuovo batti } \\
\text { il banco } \\
\text { Super }\end{array}$ & $2.0 €$ & $3.40 \mathrm{E}+07$ & 0.04167 & $2.08 \%$ & 1.241 & 0.75938 & $37.97 \%$ & 1.624 & 1.600 & 8.998 & 2.999 \\
\hline $\begin{array}{l}\text { settimana } \\
500 \text { euro }\end{array}$ & $2.0 €$ & $6.90 \mathrm{E}+07$ & 0.26345 & $13.17 \%$ & 1.301 & 0.69874 & $34.94 \%$ & 6.654 & 2.551 & 9.000 & 3.000 \\
\hline Dado 7 & $2.0 €$ & $8.20 \mathrm{E}+07$ & 0.01225 & $0.61 \%$ & 1.270 & 0.7304 & $36.52 \%$ & 4.438 & 2.150 & 11.997 & 3.464 \\
\hline Doppio fai 7 & $2.0 €$ & $8.40 \mathrm{E}+07$ & 0.00947 & $0.47 \%$ & 1.269 & 0.7308 & $36.54 \%$ & 1.066 & 1.417 & 9.867 & 3.135 \\
\hline $\begin{array}{l}\text { Natale sotto } \\
\text { l albero }\end{array}$ & $2.0 €$ & $4.40 \mathrm{E}+07$ & 0.01812 & $0.91 \%$ & 1.274 & 0.72572 & $36.29 \%$ & 7.685 & 2.723 & 10.712 & 3.261 \\
\hline Soldi soldi & $2.0 €$ & $7.50 \mathrm{E}+07$ & 0.00801 & $0.40 \%$ & 1.269 & 0.73059 & $36.53 \%$ & 2.681 & 2.003 & 11.693 & 3.407 \\
\hline $\begin{array}{l}\text { Nuovo fai } \\
\text { scopa }\end{array}$ & $2.0 €$ & $3.80 \mathrm{E}+07$ & 0.02083 & $1.04 \%$ & 1.274 & 0.72629 & $36.31 \%$ & 6.480 & 2.533 & 9.997 & 3.162 \\
\hline $\begin{array}{l}\text { Quadrifoglio } \\
\text { d oro }\end{array}$ & $2.0 €$ & $4.00 \mathrm{E}+07$ & 0.01984 & $0.99 \%$ & 1.290 & 0.7099 & $35.50 \%$ & 6.397 & 2.532 & 10.712 & 3.261 \\
\hline Bowling & $2.0 €$ & $6.00 \mathrm{E}+07$ & 0.01984 & $0.99 \%$ & 1.300 & 0.69991 & $35.00 \%$ & 7.266 & 2.673 & 10.712 & 3.261 \\
\hline $\begin{array}{l}\text { Nuovo Dato } \\
\text { matto }\end{array}$ & $2.0 €$ & $3.40 \mathrm{E}+07$ & 0.04167 & $2.08 \%$ & 1.239 & 0.76083 & $38.04 \%$ & 2.792 & 1.922 & 10.996 & 3.316 \\
\hline $\begin{array}{l}\text { Magic } \\
\text { roulette }\end{array}$ & $2.0 €$ & $9.60 \mathrm{E}+07$ & 0.02083 & $1.04 \%$ & 1.278 & 0.7225 & $36.13 \%$ & 5.819 & 2.402 & 9.997 & 3.162 \\
\hline $\begin{array}{l}\text { Turista per } \\
10 \text { anni }\end{array}$ & $2.0 €$ & $8.10 \mathrm{E}+07$ & 0.09304 & $4.65 \%$ & 1.298 & 0.70155 & $35.08 \%$ & 5.080 & 2.214 & 7.999 & 2.828 \\
\hline
\end{tabular}




\begin{tabular}{|c|c|c|c|c|c|c|c|c|c|c|c|}
\hline $\begin{array}{l}\text { Goal } \\
\text { mondiale } \\
\text { brasile }\end{array}$ & $3.0 €$ & $8.10 \mathrm{E}+07$ & 0.02976 & $0.99 \%$ & 2.028 & 0.97189 & $32.40 \%$ & 3.653 & 2.060 & 11.690 & 3.406 \\
\hline L'eredità & $3.0 €$ & $9.00 \mathrm{E}+07$ & 0.02667 & $0.89 \%$ & 2.040 & 0.95985 & $32.00 \%$ & 4.451 & 2.251 & 13.653 & 3.681 \\
\hline $\begin{array}{l}\text { Asso } \\
\text { pigliatutto }\end{array}$ & $3.0 €$ & $1.00 \mathrm{E}+08$ & 0.02381 & $0.79 \%$ & 2.004 & 0.99571 & $33.19 \%$ & 2.122 & 1.705 & 10.928 & 3.302 \\
\hline $\begin{array}{l}\text { Super sette e } \\
\text { mezzo }\end{array}$ & $3.0 €$ & $1.40 \mathrm{E}+08$ & 0.03333 & $1.11 \%$ & 2.032 & 0.96758 & $32.25 \%$ & 2.511 & 1.979 & 7.809 & 2.769 \\
\hline $\begin{array}{l}\text { Natale in } \\
\text { famiglia }\end{array}$ & $3.0 €$ & $1.10 \mathrm{E}+08$ & 0.01603 & $0.53 \%$ & 2.060 & 0.93954 & $31.32 \%$ & 4.735 & 2.182 & 9.999 & 3.162 \\
\hline $\begin{array}{l}\text { Super } \\
\text { portafortuna }\end{array}$ & $3.0 €$ & $1.10 \mathrm{E}+08$ & 0.03333 & $1.11 \%$ & 2.030 & 0.97033 & $32.34 \%$ & 3.081 & 1.910 & 9.932 & 3.148 \\
\hline $\begin{array}{l}\text { Buon } \\
\text { compleanno }\end{array}$ & $3.0 €$ & $1.10 \mathrm{E}+08$ & 0.10278 & $3.43 \%$ & 2.040 & 0.96 & $32.00 \%$ & 2.449 & 1.763 & 9.921 & 3.146 \\
\hline $\begin{array}{l}\text { Oroscopo } \\
\text { fortunato }\end{array}$ & $3.0 €$ & $1.10 \mathrm{E}+08$ & 0.03333 & $1.11 \%$ & 2.029 & 0.97067 & $32.36 \%$ & 2.753 & 1.890 & 10.709 & 3.260 \\
\hline $\begin{array}{l}\text { Puntata al } \\
\text { casinò }\end{array}$ & $3.0 €$ & $8.40 \mathrm{E}+07$ & 0.02874 & $0.96 \%$ & 2.023 & 0.97747 & $32.58 \%$ & 3.214 & 1.940 & 10.928 & 3.302 \\
\hline Gratta quiz & $3.0 €$ & $1.50 \mathrm{E}+08$ & 0.0119 & $0.40 \%$ & 1.999 & 1. & $33.37 \%$ & 5.765 & 2.438 & 11.910 & 3.401 \\
\hline $\begin{array}{l}\text { Cruciverba } \\
\text { d'oro }\end{array}$ & $3.0 €$ & $1.10 \mathrm{E}+08$ & 0.1 & $3.33 \%$ & 1.913 & 1.09 & $36.25 \%$ & 3.477 & 2.071 & 11.647 & 3.397 \\
\hline $\begin{array}{l}\text { Pazzi per lo } \\
\text { shopping }\end{array}$ & $3.0 €$ & $1.30 \mathrm{E}+08$ & 0.27835 & $9.28 \%$ & 2.070 & 0.92966 & $30.99 \%$ & 1.021 & 1.376 & 7.000 & 2.646 \\
\hline $\begin{array}{l}\text { Mappa dei } \\
\text { pirati }\end{array}$ & $3.0 €$ & $6.50 \mathrm{E}+07$ & 0.02778 & $0.93 \%$ & 1.921 & 1.08 & $35.97 \%$ & 3.711 & 2.033 & 11.923 & 3.449 \\
\hline
\end{tabular}

Table A1 Summary statistics for the entire sample of scratch-off tickets sold in Italy (continues)

\begin{tabular}{|c|c|c|c|c|c|c|c|c|c|c|c|}
\hline $\begin{array}{l}\text { Scratch-off } \\
\text { ticket }\end{array}$ & $\begin{array}{l}\text { Ticket } \\
\text { Price }\end{array}$ & $\begin{array}{c}\text { Total } \\
\text { Revenue }\end{array}$ & $\begin{array}{c}\text { Player's } \\
\text { expected } \\
\text { value } \\
\text { from the } \\
\text { jackpot }\end{array}$ & $\begin{array}{c}\text { Player's } \\
\text { expected value } \\
\text { from the } \\
\text { jackpot ( } \% \\
\text { price) }\end{array}$ & $\begin{array}{c}\text { Total } \\
\text { expected } \\
\text { value from } \\
\text { the ticket }\end{array}$ & $\begin{array}{l}\text { Players' net } \\
\text { loss (in } \\
\text { euro) }\end{array}$ & $\begin{array}{l}\text { Players' net loss } \\
\text { (\% price) }\end{array}$ & $\begin{array}{c}\text { Kurtosis } \\
\text { (gambling } \\
\text { odds) }\end{array}$ & $\begin{array}{c}\text { Skewness } \\
\text { (gambling } \\
\text { odds) }\end{array}$ & $\begin{array}{c}\text { Kurtosis of } \\
\text { prizes }\end{array}$ & $\begin{array}{c}\text { Skewness } \\
\text { of prizes }\end{array}$ \\
\hline Il forziere & $5.0 €$ & $2.50 \mathrm{E}+08$ & 0.05952 & $1.19 \%$ & 3.599 & 1.40 & $28.01 \%$ & 2.353 & 1.898 & 9.731 & 3.108 \\
\hline Viva l estate & $5.0 €$ & $1.30 \mathrm{E}+08$ & 0.07576 & $1.52 \%$ & 3.488 & 1.51 & $30.24 \%$ & 6.042 & 2.435 & 11.988 & 3.462 \\
\hline $\begin{array}{l}\text { Battaglia } \\
\text { navale }\end{array}$ & $5.0 €$ & $3.00 \mathrm{E}+08$ & 0.04167 & $0.83 \%$ & 3.528 & 1.47 & $29.43 \%$ & 6.443 & 2.489 & 10.000 & 3.162 \\
\hline $\begin{array}{l}\text { Arriba la } \\
\text { fortuna }\end{array}$ & $5.0 €$ & $2.50 \mathrm{E}+08$ & 0.06944 & $1.39 \%$ & 3.499 & 1.50 & $30.03 \%$ & 5.705 & 2.349 & 9.997 & 3.162 \\
\hline
\end{tabular}




\begin{tabular}{|c|c|c|c|c|c|c|c|c|c|c|c|}
\hline Royal black & $5.0 €$ & $2.00 \mathrm{E}+08$ & 0.03788 & $0.76 \%$ & 3.551 & 1.45 & $28.97 \%$ & 3.006 & 2.100 & 12.672 & 3.546 \\
\hline $\begin{array}{l}\text { Auguri di } \\
\text { natale }\end{array}$ & $5.0 €$ & $1.40 \mathrm{E}+08$ & 0.07246 & $1.45 \%$ & 3.551 & 1.45 & $28.97 \%$ & 3.718 & 2.059 & 10.989 & 3.314 \\
\hline Serata vip & $5.0 €$ & $1.10 \mathrm{E}+08$ & 0.04529 & $0.91 \%$ & 3.573 & 1.43 & $28.54 \%$ & 5.519 & 2.462 & 13.997 & 3.741 \\
\hline $\begin{array}{l}\text { Texas } \\
\text { casinò }\end{array}$ & $5.0 €$ & $2.30 \mathrm{E}+08$ & 0.08681 & $1.74 \%$ & 3.570 & 1.43 & $28.60 \%$ & 3.626 & 2.051 & 9.989 & 3.160 \\
\hline $\begin{array}{l}10 \\
\text { anniversario }\end{array}$ & $5.0 €$ & $2.70 \mathrm{E}+08$ & 0.05482 & $1.10 \%$ & 3.564 & 1.44 & $28.72 \%$ & 1.987 & 1.714 & 7.991 & 2.826 \\
\hline Miliardario & $5.0 €$ & $5.00 \mathrm{E}+08$ & 0.09921 & $1.98 \%$ & 3.500 & 1.50 & $30.00 \%$ & 5.467 & 2.398 & 10.782 & 3.249 \\
\hline $\begin{array}{l}\text { Doppia } \\
\text { sfida }\end{array}$ & $5.0 €$ & $3.20 \mathrm{E}+08$ & 0.07716 & $1.54 \%$ & 3.579 & 1.42 & $28.41 \%$ & 3.209 & 1.980 & 9.989 & 3.160 \\
\hline $20 X$ & $5.0 €$ & $2.50 \mathrm{E}+08$ & 0.03968 & $0.79 \%$ & 3.511 & 1.49 & $29.79 \%$ & 3.019 & 2.087 & 12.987 & 3.603 \\
\hline Cruciverba & $5.0 €$ & $1.50 \mathrm{E}+08$ & 0.08333 & $1.67 \%$ & 3.472 & 1.53 & $30.57 \%$ & 4.185 & 2.066 & 8.000 & 2.828 \\
\hline $\begin{array}{l}\text { Turista per } \\
\text { sempre }\end{array}$ & $5.0 €$ & $5.00 \mathrm{E}+08$ & 0.50347 & $10.07 \%$ & 3.629 & 1.37 & $27.42 \%$ & 5.299 & 2.387 & 12.961 & 3.598 \\
\hline $\begin{array}{l}\text { Ricca } \\
\text { nevicata }\end{array}$ & $5.0 €$ & $1.50 \mathrm{E}+08$ & 0.03415 & $0.68 \%$ & 3.522 & 1.48 & $29.56 \%$ & 2.707 & 1.996 & 10.777 & 3.246 \\
\hline $\begin{array}{l}\text { Nuovo } \\
\text { miliardario }\end{array}$ & $5.0 €$ & $7.10 \mathrm{E}+08$ & 0.0947 & $1.89 \%$ & 3.601 & 1.40 & $27.97 \%$ & 6.085 & 2.479 & 10.782 & 3.249 \\
\hline Oro e rubini & $5.0 €$ & $2.20 \mathrm{E}+08$ & 0.10417 & $2.08 \%$ & 3.567 & 1.43 & $28.67 \%$ & 5.520 & 2.339 & 10.989 & 3.314 \\
\hline $\begin{array}{l}\text { Super } \\
\text { settimana } \\
1500 \text { euro } \\
\text { Nuovo }\end{array}$ & $5.0 €$ & $1.70 \mathrm{E}+08$ & 0.52686 & $10.54 \%$ & 3.520 & 1.48 & $29.60 \%$ & 3.892 & 2.069 & 8.999 & 3.000 \\
\hline $\begin{array}{l}\text { turista per } \\
\text { sempre }\end{array}$ & $5.0 €$ & $2.70 \mathrm{E}+08$ & 0.38516 & $7.70 \%$ & 3.630 & 1.37 & $27.41 \%$ & 5.311 & 2.387 & 12.974 & 3.601 \\
\hline $\begin{array}{l}\text { Oroe } \\
\text { diamanti }\end{array}$ & $10.0 €$ & $3.60 \mathrm{E}+08$ & 0.33333 & $3.33 \%$ & 7.733 & 2.27 & $22.67 \%$ & 1.783 & 1.819 & 9.983 & 3.159 \\
\hline $50 X$ & $10.0 €$ & $2.40 \mathrm{E}+08$ & 0.16667 & $1.67 \%$ & 7.618 & 2.38 & $23.82 \%$ & 9.726 & 3.069 & 13.908 & 3.725 \\
\hline $\begin{array}{l}\text { Mega } \\
\text { doppia sfida }\end{array}$ & $10.0 €$ & $4.10 \mathrm{E}+08$ & 0.2451 & $2.45 \%$ & 7.696 & 2.30 & $23.04 \%$ & 6.628 & 2.575 & 11.979 & 3.460 \\
\hline $\begin{array}{l}\text { Botta di } \\
\text { fortuna }\end{array}$ & $10.0 €$ & $4.10 \mathrm{E}+07$ & 0.73529 & $7.35 \%$ & 7.689 & 2.31 & $23.11 \%$ & 2.962 & 1.754 & 7.000 & 2.646 \\
\hline $\begin{array}{l}\text { Vegas } \\
\text { casinò }\end{array}$ & $10.0 €$ & $4.00 \mathrm{E}+08$ & 0.19841 & $1.98 \%$ & 7.807 & 2.19 & $21.93 \%$ & 4.272 & 2.232 & 10.993 & 3.315 \\
\hline $\begin{array}{l}\text { I tesori del } \\
\text { pascià } \\
\text { Mega }\end{array}$ & $10.0 €$ & $2.00 \mathrm{E}+08$ & 0.29762 & $2.98 \%$ & 7.501 & 2.50 & $24.99 \%$ & 4.176 & 2.047 & 9.999 & 3.162 \\
\hline $\begin{array}{l}\text { turista per } \\
\text { sempre }\end{array}$ & $10.0 €$ & $3.50 \mathrm{E}+08$ & 1.13 & $11.28 \%$ & 7.458 & 2.54 & $25.42 \%$ & 3.677 & 2.142 & 10.973 & 3.311 \\
\hline $\begin{array}{l}\text { Soldi cash } \\
500 \text { 10euro }\end{array}$ & $10.0 €$ & $2.10 \mathrm{E}+08$ & 3 & $33.30 \%$ & 7.583 & 2.42 & $24.17 \%$ & -0.560 & 0.839 & 5.888 & 2.421 \\
\hline Milioneuro & $10.0 €$ & $1.60 \mathrm{E}+08$ & 0.37879 & $3.79 \%$ & 7.697 & 2.30 & $23.03 \%$ & 7.699 & 2.661 & 12.999 & 3.605 \\
\hline $\begin{array}{l}\text { Nuovo mega } \\
\text { miliardario }\end{array}$ & $10.0 €$ & $7.80 \mathrm{E}+08$ & 0.25641 & $2.56 \%$ & 7.696 & 2.30 & $23.04 \%$ & 3.160 & 2.071 & 10.997 & 3.316 \\
\hline $\begin{array}{l}500 \text { Milioni } \\
\text { super cash }\end{array}$ & $20.0 €$ & $6.30 \mathrm{E}+08$ & 0.44192 & $2.21 \%$ & 15.875 & 4.12 & $20.62 \%$ & 1.430 & 1.623 & 11.367 & 3. \\
\hline
\end{tabular}




\begin{tabular}{|c|c|c|c|c|c|c|c|c|c|c|c|}
\hline $\begin{array}{l}\text { Magnifici } \\
10000\end{array}$ & $20.0 €$ & $2.90 \mathrm{E}+08$ & 3 & $15.40 \%$ & 16.248 & 3.75 & $18.76 \%$ & 6.164 & 2.459 & 3.281 & 1.942 \\
\hline $\begin{array}{l}\text { Fantastici } \\
1000\end{array}$ & $20.0 €$ & $1.20 \mathrm{E}+08$ & 4 & $20.00 \%$ & 16.147 & 3.85 & $19.27 \%$ & 5.289 & 2.284 & 1.773 & 1.583 \\
\hline $\begin{array}{l}\text { Nuovo maxi } \\
\text { miliardario }\end{array}$ & $20.0 €$ & $1.20 \mathrm{E}+09$ & 0.66667 & $3.33 \%$ & 17.013 & 2.99 & $14.93 \%$ & 8.963 & 2.961 & 9.988 & 3.160 \\
\hline
\end{tabular}

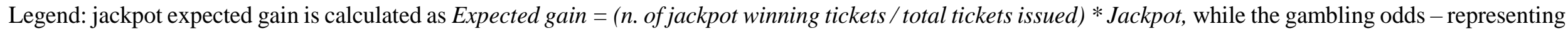

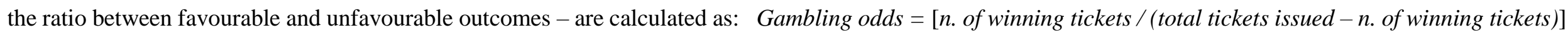


Figure A1. Trends of expected gains and gambling odds for all the Italian scratch off tickets

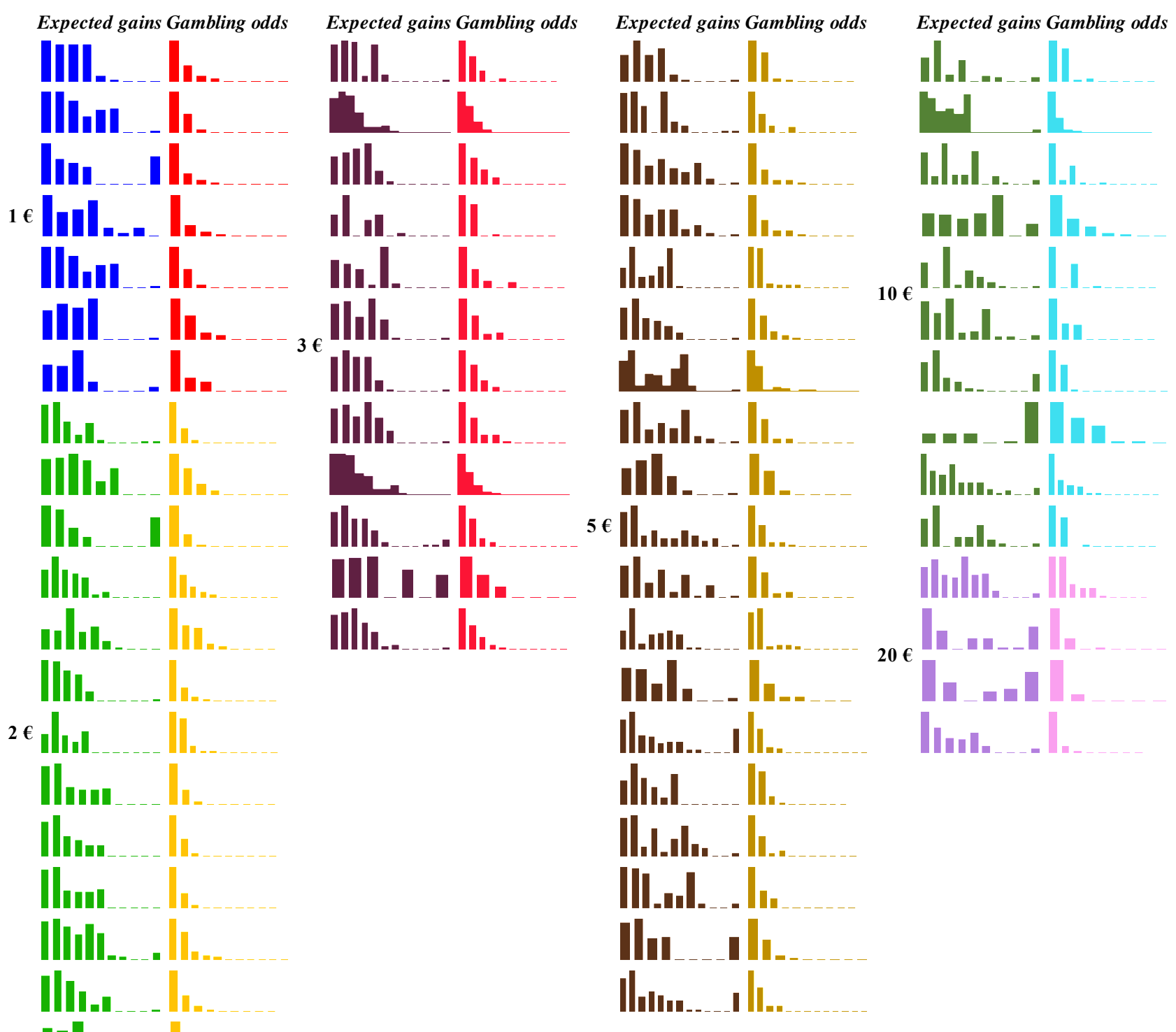


Figure A2. Examples of expected profits associated to jackpots per scratch-off price category

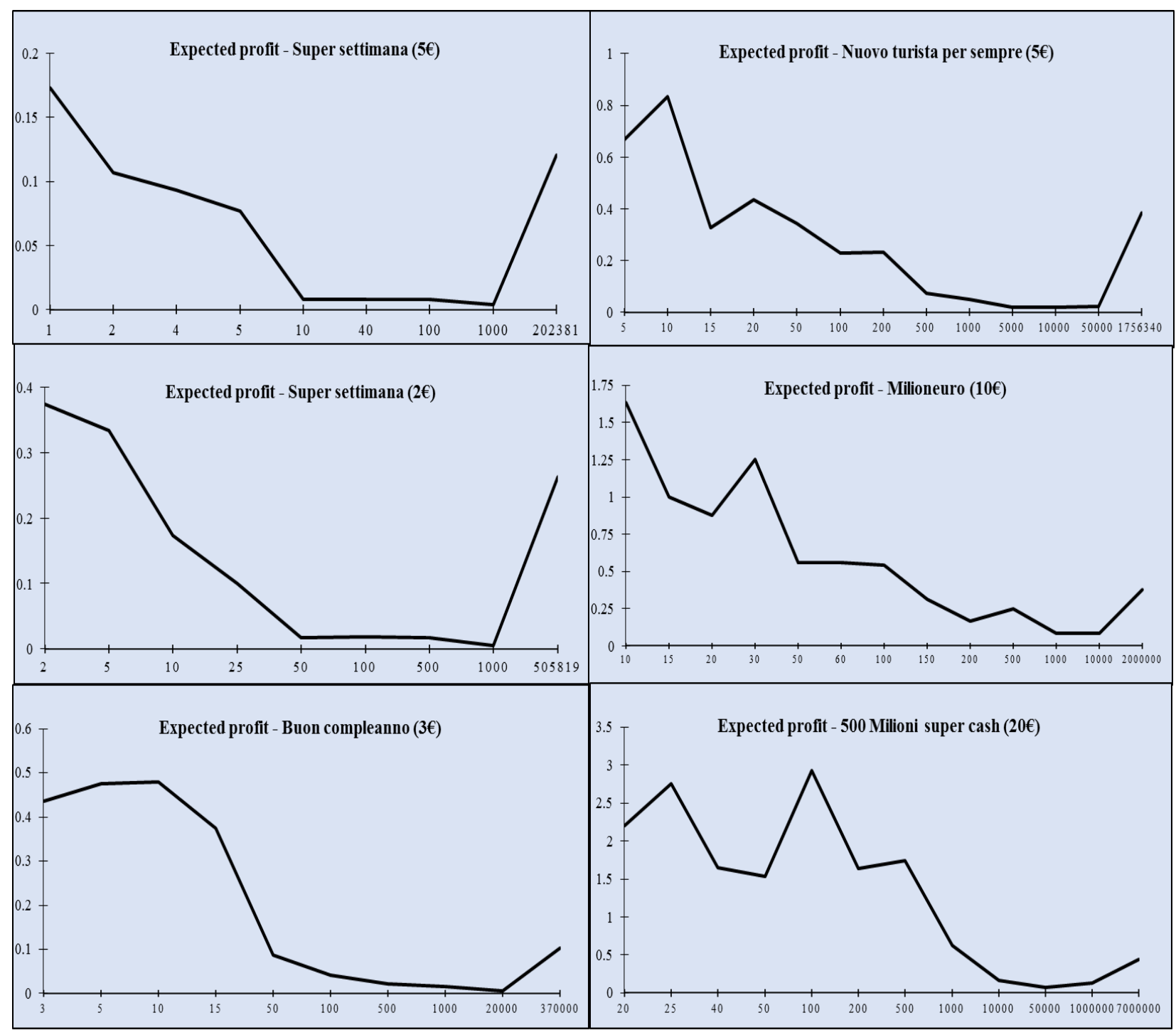


Figure A3. Examples of gambling odds associated to prizes per price category with highest jackpot

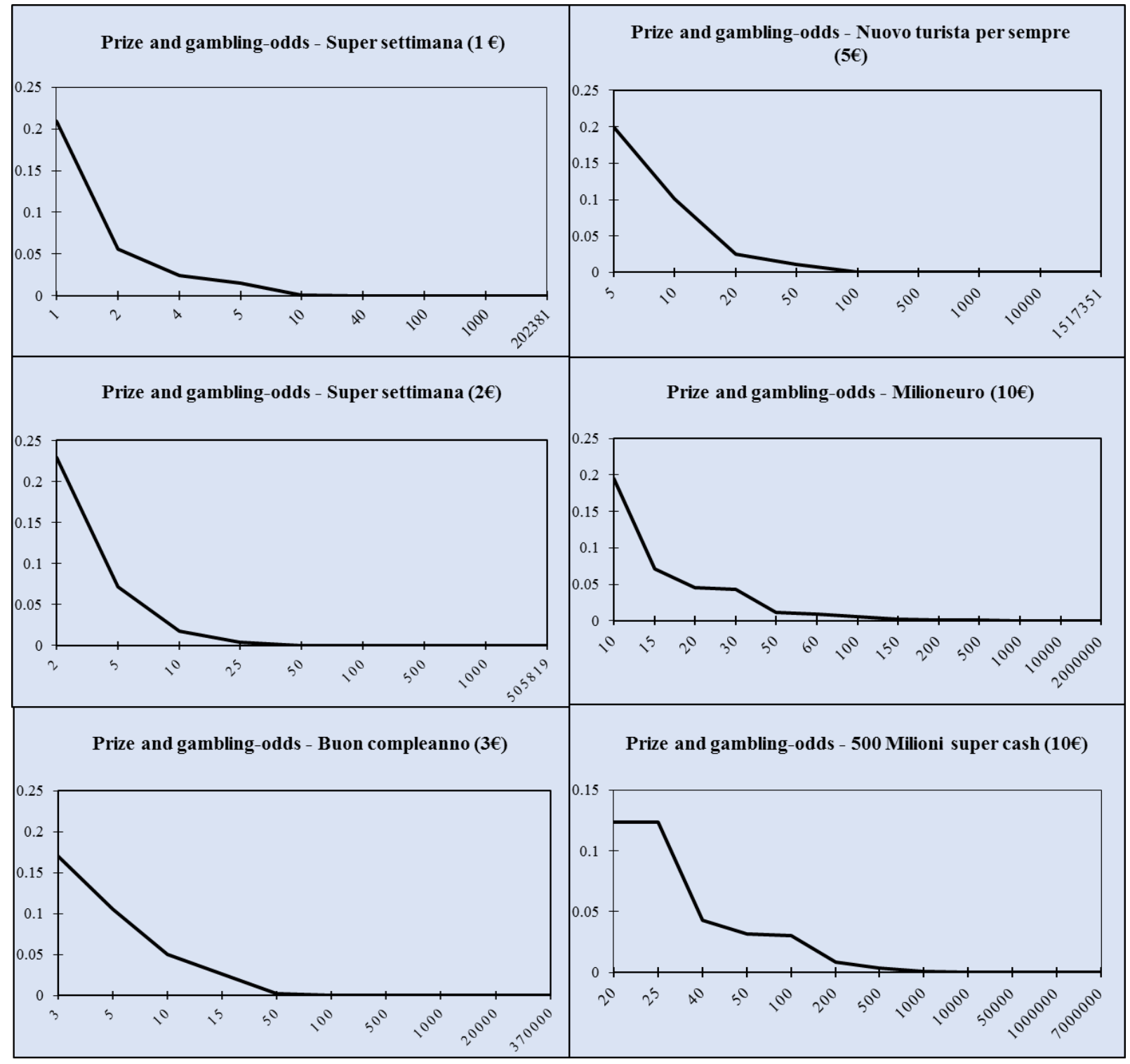


